\title{
An affinity/avidity model of peripheral T cell regulation
}

\author{
Hong Jiang,, ${ }^{1}$ Yilun Wu, ${ }^{1}$ Bitao Liang, ${ }^{1}$ Zongyu Zheng,, ${ }^{1}$ Guomei Tang, ${ }^{1}$ Jean Kanellopoulos, ${ }^{2}$ \\ Mark Soloski, ${ }^{3}$ Robert Winchester, ${ }^{1}$ Itamar Goldstein, ${ }^{1}$ and Leonard Chess ${ }^{1}$
}

1Department of Medicine, College of Physicians and Surgeons, Columbia University, New York, New York, USA. 2Pasteur Institute, Paris, France. 3Johns Hopkins Medical School, Baltimore, Maryland, USA.

\begin{abstract}
We show in these studies that Qa-1-dependent $\mathrm{CD8}^{+} \mathrm{T}$ cells are involved in the establishment and maintenance of peripheral self tolerance as well as facilitating affinity maturation of $\mathrm{CD}^{+} \mathrm{T}$ cells responding to foreign antigen. We provide experimental evidence that the strategy used by the Qa-1-dependent $\mathrm{CDB}^{+} \mathrm{T}$ cells to accomplish both these tasks in vivo is to selectively downregulate $T$ cell clones that respond to both self and foreign antigens with intermediate, not high or low, affinity/avidity. Thus, the immune system evolved to regulate peripheral immunity using a unified mechanism that efficiently and effectively permits the system to safeguard peripheral self tolerance yet promote the capacity to deal with foreign invaders.
\end{abstract}

\section{Introduction}

The essential function of the immune system is to mount effective immune responses to virtually any foreign antigens but avoid harmful immune responses to self. How developing $\mathrm{T}$ cells maintain tolerance to self while achieving affinity maturation in response to foreign antigen in the periphery is one of the most important phenomena in immunology but is not yet completely understood. Nevertheless, many studies indicate that both central thymic and peripheral mechanisms are important. For example, thymocytes expressing TCRs with high affinity/avidity for MHC/ self peptide complexes undergo apoptosis and are deleted centrally in the thymus (1). However, some self-reactive T cells with intermediate affinity/avidity for self antigen escape thymic negative selection and are released into the periphery. Although these selfreactive $\mathrm{T}$ cells display lower affinity/avidity for $\mathrm{MHC} /$ self peptide complexes, they are capable of self peptide-driven proliferation, and some may differentiate into potentially pathogenic effector cells (2-4). It is clear that in order to avoid pathogenic autoimmunity, peripheral regulatory mechanisms are required to fine-tune the self-reactive TCR repertoire and limit the clonal expansion of these potentially pathogenic self-reactive clones with TCRs whose affinity/avidity is not high enough to cause their intrathymic elimination. These peripheral mechanisms are thought to include activation-induced apoptosis, cytokine interactions, and regulatory cells. We provide evidence here that one of the mechanisms for such peripheral regulation of the immune system involves Qa-1dependent $\mathrm{CD}^{+} \mathrm{T}$ cells.

Previously, a pathway of immunoregulation mediated by the Qa-1dependent $\mathrm{CD}^{+} \mathrm{T}$ cells was identified (5). Heightened interest in these regulatory $\mathrm{CD}^{+} \mathrm{T}$ cells arose in the early 1990 s from studies of experimental allergic encephalomyelitis (EAE), which provided evidence that $\mathrm{CD}^{+} \mathrm{T}$ cells play a key role in both inducing resistance to autoimmune EAE and abrogating recurrent relapsing epi-

Nonstandard abbreviations used: EAE, experimental allergic encephalomyelitis; $\mathrm{EI}_{50}, \mathrm{E} / \mathrm{T}$ needed for half maximum inhibition; $\mathrm{E} / \mathrm{T}$, effector-to-target ratio; HEL, hen egg lysozyme.

Conflict of interest: The authors have declared that no conflict of interest exists.

Citation for this article: J. Clin. Invest. 115:302-312 (2005).

doi:10.1172/JCI200523879. sodes of autoimmunity in vivo $(6,7)$. Regulatory $\mathrm{CD}^{+} \mathrm{T}$ cells were further isolated, and their capacity to specifically interact with and downregulate activated $\mathrm{CD} 4^{+} \mathrm{T}$ cells was found to be blocked by antibodies to CD8, to $\alpha \beta$ TCR, and to the MHC class Ib molecule Qa-1 (8-10). These data suggested that regulatory $\mathrm{CD}^{+} \mathrm{T}$ cells specifically inhibit activated autologous $\mathrm{CD}^{+} \mathrm{T}$ cells via $\alpha \beta$ TCR recognition of Qa-1/self peptide complexes expressed on activated $\mathrm{CD}^{+} \mathrm{T}$ cells. The direct in vivo molecular evidence that $\mathrm{Qa}-1$ is in fact essential for the regulatory functions of $\mathrm{CD}^{+} \mathrm{T}$ cells in vivo has come from recent studies of Qa-1 KO mice showing that mice deficient in Qa-1 are impaired in their capacity to become resistant to the second induction of EAE (11).

Although we previously showed that $\mathrm{CD}^{+} \mathrm{T}$ cells protect mice from EAE by selectively downregulating some but not all MBP-reactive $\mathrm{CD}^{+} \mathrm{T}$ cells that are enriched in the potentially encephalitogenic clones in vivo (4), the precise targets that are selectively downregulated by the $\mathrm{CD}^{+} \mathrm{T}$ cells were not identified. Because $\mathrm{T}$ cell clones with higher outgrowth potential are likely to have higher affinity/avidity, the EAE data suggested that the affinity/avidity of $\mathrm{T}$ cell clones might somehow dictate their susceptibility to downregulation by the $\mathrm{CD} 8^{+} \mathrm{T}$ cells.

To test this hypothesis and further delineate the biological functions of the regulatory $\mathrm{CD} 8^{+} \mathrm{T}$ cells in controlling peripheral immunity to both self and foreign antigens, we have studied the $\mathrm{CD}^{+} \mathrm{T}$ cell regulation of immune responses to a conventional antigen, hen egg lysozyme (HEL), in BALB/c mice. Previously, HEL Tg mice have been generated in the BALB/c background and have been widely used to study mechanisms of self tolerance (12-17). Because HEL represents a foreign antigen in WT mice but a self antigen in HEL Tg mice, studying immune response to HEL in both animals permits direct delineation of the cellular and molecular mechanisms by which $\mathrm{CD}^{+} \mathrm{T}$ cells control the peripheral TCR repertoire to both self and foreign antigens. We provide evidence that the Qa-1-dependent $\mathrm{CD}^{+} \mathrm{T}$ cells participate in regulation of peripheral immunity by preferentially downregulating $\mathrm{T}$ cells of intermediate affinity/avidity to both self and foreign antigens. Thus, these regulatory cells play an important role in both the establishment and the maintenance of peripheral self tolerance to HEL in Tg mice and T cell affinity maturation to HEL in WT mice. 

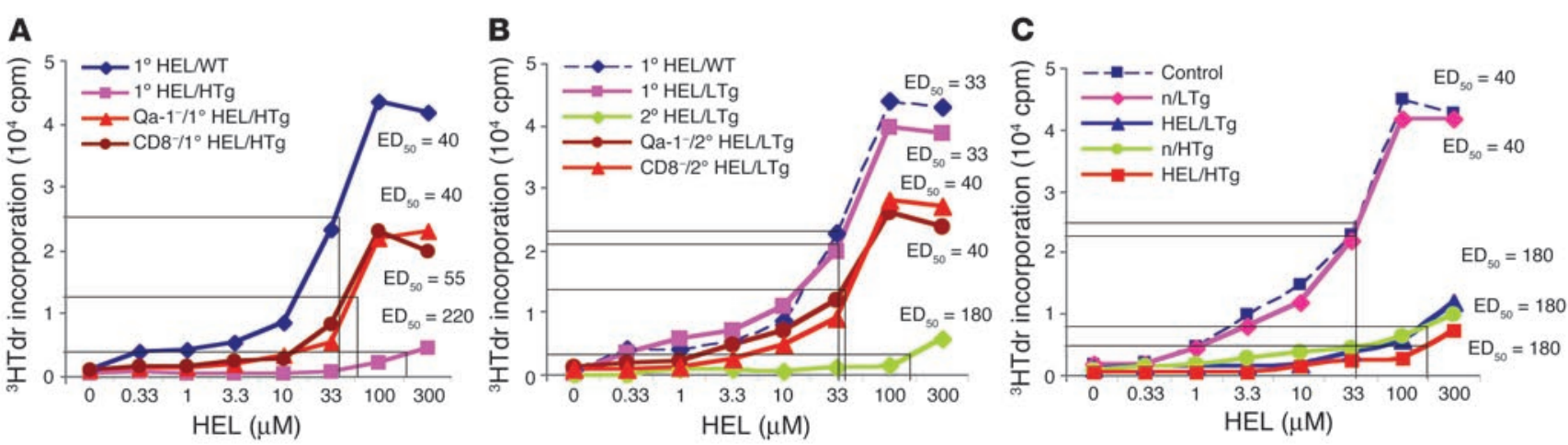

\section{Figure 1}

Qa-1-dependent CD8 ${ }^{+} \mathrm{T}$ cells are involved in the establishment and maintenance of peripheral self tolerance to HEL in HEL Tg mice. (A) The unresponsiveness to HEL in HEL high Tg mice could be broken by treatment with anti-CD8 and anti-Qa-1 mAbs. HEL immunization and in vivo $\mathrm{mAb}$ treatment were performed and $\mathrm{CD} 4^{+} \mathrm{T}$ cells were purified from pooled draining lymph node cells from different groups of mice and assayed in a T cell proliferation assay as described in Methods. Data are representative of 4 separate experiments with $2-4$ mice per group. (B) CD8+ T cells regulate immune response to self antigen HEL in HEL low Tg mice. Experiments were performed as described in Methods. Data are representative of 6 separate experiments with 2-4 mice per group. (C) $C D 8^{+} \mathrm{T}$ cells downregulate the primary immune responses to $\mathrm{HEL}$ in $\mathrm{HEL}$ low Tg mice when adoptively transferred. $C D 8^{+} \mathrm{T}$ cells were injected i.v. into recipient mice, and the mice were immunized with $\mathrm{HEL} 1$ day later. The $\mathrm{CD}^{+} \mathrm{T}$ cells were isolated from pooled lymph node cells of recipient mice 7-9 days after the immunization, and T cell proliferation assays were performed. Data are representative of 4 separate experiments with $2-4$ mice per group. Control, no transfer; $n / L T g, C D 8^{+} T$ cells transferred from naive HEL low Tg mice; HEL/LTg, CD8 ${ }^{+} \mathrm{T}$ cells transferred from $2^{\circ} \mathrm{HEL}$-immunized HEL low $\mathrm{Tg}$ mice; $\mathrm{n} / \mathrm{HTg}, \mathrm{CD}^{+} \mathrm{T}$ cells transferred from naive HEL high Tg mice; HEL/HTg, CD8 ${ }^{+} \mathrm{T}$ cells transferred from $1^{\circ} \mathrm{HEL}$-immunized HEL high $\mathrm{Tg}$ mice. ${ }^{3} \mathrm{HTdr},{ }^{3} \mathrm{H}$-thymidine.

\section{Results}

$C D 8^{+} T$ cells are involved in the control of peripheral self tolerance in $H E L$ $\mathrm{Tg}$ mice. In Tg mice expressing HEL under the control of a ubiquitous promoter, HEL is present in the serum and thymus throughout the establishment of the $\mathrm{T}$ cell repertoire (12). There are 2 immunological $\mathrm{T}$ cell response phenotypes observed in HEL Tg mice, which are dictated by the serum level of HEL. High Tg mice (serum level greater than $10 \mathrm{ng} / \mathrm{ml}$ ) are tolerant and there is little or no $\mathrm{T}$ cell proliferation in response to HEL, whereas, in low $\mathrm{Tg}$ mice (serum level less than $2 \mathrm{ng} / \mathrm{ml}$ ), T cells do respond to HEL, in vitro, following the primary HEL immunization (12-14).

We first investigated the function of $\mathrm{CD}^{+} \mathrm{T}$ cells in the HEL high Tg mice. As shown in Figure 1A, the WT mice responded briskly to HEL, whereas the HEL high Tg mice treated with control Ig were tolerant to HEL. The conventional interpretation of this result is that the lack of response in the HEL high Tg mice simply reflects the deletion of HEL-reactive $T$ cells intrathymically by negative selection. However, as shown, in mice that were depleted of $\mathrm{CD}^{+}$cells or treated with anti-Qa-1 mAb before the immunization, immune responses to HEL were detected, although at a lower magnitude than in the WT mice (Figure 1A). This indicates that even though thymic negative selection deletes the majority of self-reactive T cells with high affinity/avidity, some HEL-reactive $T$ cells escape thymic negative selection and are released into the periphery, where they are controlled by peripheral regulatory mechanisms. Moreover, the data clearly suggest that Qa-1-dependent $\mathrm{CD}^{+} \mathrm{T}$ cells play a role in maintaining peripheral tolerance.

We then studied the primary $\left(1^{\circ} \mathrm{HEL}\right)$ and the secondary $\left(2^{\circ} \mathrm{HEL}\right)$ immune responses to HEL in vivo in HEL low Tg mice in the presence and absence of CD8 ${ }^{+} \mathrm{T}$ cells $\left(\mathrm{CD} 8^{-} / 2^{\circ} \mathrm{HEL}\right)$ and in mice treated with anti-Qa-1 mAb (Qa-1- $\left./ 2^{\circ} \mathrm{HEL}\right)$. As previously reported, unlike HEL high Tg mice, HEL low Tg mice do respond to HEL following the primary immunization (12-14). Interestingly, self tolerance to HEL in the HEL low Tg mice is reflected in the secondary immune response to HEL. As shown in Figure 1B, unlike the vigorous response to the secondary HEL challenge in WT mice (see Figure 3A), the secondary HEL response in HEL low Tg mice mimicked the primary HEL response in HEL high Tg mice, in which virtually no $\mathrm{T}$ cell response was observed. Importantly, $\mathrm{CD}^{+} \mathrm{T}$ cell depletion or anti-Qa-1 mAb treatment reversed the low responsiveness to HEL in the mice that received secondary HEL immunization, as shown by increased $\mathrm{T}$ cell proliferation. These studies demonstrate that Qa-1-dependent $C D 8^{+} \mathrm{T}$ cells are also involved in the regulation of peripheral autoimmunity in HEL low Tg mice, in which the tolerance to self antigen HEL is only completed during the secondary HEL response. Considering that $\mathrm{T}$ cells from the primary-immunized low $\mathrm{Tg}$ mice, which possess $\mathrm{CD}^{+} \mathrm{T}$ cells, do respond to HEL in vitro, these data are compatible with the idea that regulatory $\mathrm{CD}^{+} \mathrm{T}$ cells require priming during the primary immune response in vivo in order to downregulate the secondary HEL response. This is consistent with previous observations in the EAE model (4).

$C D 8^{+} T$ cells isolated from both HEL high and HEL low Tg mice suppress the in vivo primary immune response to HEL when adoptively transferred into HEL low $\mathrm{Tg}$ mice. To provide further evidence that $\mathrm{CD}^{+} \mathrm{T}$ cells primed during the primary HEL response downregulate HEL-reactive $\mathrm{CD}^{+} \mathrm{T}$ cells in vivo, the function of the $\mathrm{CD} 8^{+} \mathrm{T}$ cells isolated from HEL Tg mice was further tested by adoptive transfer of the $\mathrm{CD}^{+} \mathrm{T}$ cells to naive HEL low Tg mice. The responses to HEL in recipient mice were evaluated by $\mathrm{T}$ cell proliferation assay. As shown in Figure 1C, control mice receiving no transfer as well as mice receiving $\mathrm{CD}^{+} \mathrm{T}$ cells from naive HEL low $\mathrm{Tg}$ mice showed the primary response typically seen in the HEL low Tg mice. In contrast, mice receiving $\mathrm{CD}^{+} \mathrm{T}$ cells from the $1^{\circ} \mathrm{HEL}$ high $\mathrm{Tg}$ mice or $2^{\circ}$ HEL low Tg mice showed marked suppression of the primary response. This result demonstrates that adoptive transfer of $\mathrm{CD}^{+} \mathrm{T}$ cells isolated from either $1^{\circ} \mathrm{HEL}$ high Tg mice or $2^{\circ}$ HEL low Tg mice suppressed the in vivo primary immune response to HEL in HEL low Tg mice. Interestingly, CD8 ${ }^{+} \mathrm{T}$ cells isolated from unimmunized naive HEL high $\mathrm{Tg}$ mice also inhibited the primary HEL immune response in the recipient HEL low Tg mice. The 
Table 1

Summary of HEL-specific CD4+ T cell clones tested in the CFSE assay

\begin{tabular}{|c|c|c|c|c|c|c|}
\hline \multirow[t]{2}{*}{ Clones } & \multirow{2}{*}{$\begin{array}{l}\text { Affinity/ } \\
\text { avidity }\end{array}$} & \multirow[t]{2}{*}{$\mathrm{ED}_{50}$} & \multirow[t]{2}{*}{$\mathbf{V} \beta$} & \multirow{2}{*}{$\begin{array}{l}\text { HEL peptide } \\
\text { specificity }\end{array}$} & \multicolumn{2}{|c|}{ Inhibition by the CD8+ $T$ cells } \\
\hline & & & & & Max inhibition (\%) & $\mathrm{El}_{50}(\mathrm{E} / \mathrm{T})$ \\
\hline 9E4 & High & $<1$ & 8.2 & $103-117$ & 0 & $>10$ \\
\hline $14 \mathrm{~F} 7$ & High & $<1$ & 8.2 & $103-117$ & 0 & $>10$ \\
\hline $19 F 6$ & High & $<1$ & 6 & $103-117$ & 0 & $>10$ \\
\hline $9 \mathrm{H} 10$ & Inter & 2 & 8.3 & $103-117$ & 9.8 & 9.5 \\
\hline 17D3 & Inter & 2 & 8.2 & HEL & 10.2 & 9.0 \\
\hline $16 \mathrm{~B} 7$ & Inter & 3 & 8.1 & HEL & 28.5 & 6.5 \\
\hline $20 \mathrm{E} 4$ & Inter & 3 & 8.1 & HEL & 26.7 & 5.5 \\
\hline $17 D 7$ & Inter & 3 & 8.1 & HEL & 23.5 & 5.0 \\
\hline $33 \mathrm{C9}$ & Inter & 3 & 8.2 & $74-96$ & 25.1 & 6.0 \\
\hline $10 \mathrm{H} 9$ & Inter & 3 & 8.2 & $103-117$ & 34.5 & 5.5 \\
\hline 17B3 & Inter & 3 & 8.1 & HEL & 38.2 & 4.0 \\
\hline 17D10 & Inter & 3.8 & 6 & HEL & 25.8 & 1.5 \\
\hline $20 \mathrm{G} 10$ & Inter & 4 & 8.2 & $103-117$ & 30.5 & 1 \\
\hline $9 \mathrm{C5}$ & Inter & 5 & 8.3 & $103-117$ & 28.1 & 0.3 \\
\hline $13 \mathrm{C} 7$ & Inter & 7 & 6 & $103-117$ & 43.8 & 0.3 \\
\hline $18 \mathrm{G} 6$ & Inter & 10 & 8.1 & HEL & 29.3 & 0.1 \\
\hline $18 \mathrm{C} 3$ & Inter & 10 & 6 & $103-117$ & 35.6 & 0.1 \\
\hline $13 \mathrm{Cg}$ & Inter & 10 & 6 & HEL & 46.5 & 0.2 \\
\hline 17E11 & Inter & 12 & 8.2 & HEL & 32.5 & 0.4 \\
\hline $18 \mathrm{E} 2$ & Inter & 15 & 8.3 & HEL & 25.5 & 6.3 \\
\hline $39 F 3$ & Inter & 15 & 8.2 & $74-96$ & 18.9 & 7.0 \\
\hline $44 \mathrm{H} 7$ & Low & 20 & 6 & $74-96$ & 0 & $>10$ \\
\hline $12 \mathrm{D} 7$ & Low & 22 & 6 & $103-117$ & 0 & $>10$ \\
\hline $8 \mathrm{E} 9$ & Low & 33 & 8.1 & HEL & 0 & $>10$ \\
\hline $13 F 2$ & Low & 33 & 6 & $103-117$ & 0 & $>10$ \\
\hline $14 \mathrm{E} 9$ & Low & 33 & 8.2 & HEL & 0 & $>10$ \\
\hline $18 \mathrm{D} 4$ & Low & 33 & 6 & HEL & 0 & $>10$ \\
\hline $34 C 11$ & Low & 33 & 8.2 & $74-96$ & 0 & $>10$ \\
\hline
\end{tabular}

HEL-specific clones were generated as described in Methods. The peptide specificity of each clone was determined by priming of the clones with peptides HEL103-117 and HEL74-96. The HEL-specific clones that were not reactive to either peptide were described as HEL specific. Inter, intermediate; Max, maximum. results thus strongly suggest that the regulatory $\mathrm{CD}^{+} \mathrm{T}$ cells may be "internally" induced in the HEL high Tg mice. This may explain why HEL high Tg mice mount no response to the HEL stimulation during the primary response. Taken together, these data suggest that tolerance to HEL in both high and low Tg mice is mediated, in part, by Qa-1-dependent $\mathrm{CD}^{+} \mathrm{T}$ cells. However, in the high $\mathrm{Tg}$ mice the regulatory $\mathrm{CD}^{+} \mathrm{T}$ cells are induced internally, but in the low $\mathrm{Tg}$ mice their induction requires additional priming with self antigen HEL (see Discussion).

Qa-1-dependent $C D 8^{+} T$ cells downregulate HEL-reactive clones based on their affinity/avidity for HEL. We next directly tested whether the affinity/avidity of target $\mathrm{T}$ cells is one of the deciding factors that enable the $\mathrm{CD}^{+} \mathrm{T}$ cells to distinguish the target from nontarget $\mathrm{T}$ cells. Thus, a panel of HEL-reactive $\mathrm{CD}^{+} \mathrm{T}$ cell clones was generated as described in Methods (10). It is known that in BALB/c mice $\mathrm{CD}^{+} \mathrm{T}$ cells respond to several HEL peptides (12-17). For example, it is well established that in the $\mathrm{CD}^{+} \mathrm{T}$ cell response to the whole HEL protein the immunodominant peptide is 103-117 (13); however, responses to subdominant peptides are also observed (15). In order to generate a diverse set of clones with varying affinities and peptide specificities, we chose to immunize mice with high doses of HEL, which increases the likelihood of generating HEL clones at the low end of the spectrum of affinities (18). In addi- tion, we used limiting-dilution cloning immediately after isolation of the $\mathrm{CD} 4^{+} \mathrm{T}$ cells from draining lymph nodes to increase the probability of obtaining intermediate-affinity/avidity and, especially, low-affinity/avidity $\mathrm{T}$ cell clones with specificity to different peptides. We selected 28 HEL-reactive clones, including both $\mathrm{V} \beta 8^{+}$and $\mathrm{V} \beta 6^{+}$clones, and determined the affinity/avidity of each clone by measuring the $\mathrm{ED}_{50}$ using the antigen dose-response curve in a $\mathrm{T}$ cell proliferation assay $(19,20)$. Clones of $\mathrm{ED}_{50}$ less than $1 \mu \mathrm{M}$ were considered to be of high affinity/avidity, whereas clones with $\mathrm{ED}_{50}$ of $20 \mu \mathrm{M}$ or greater were considered to be of low affinity/avidity. The remaining clones were arbitrarily considered to be of intermediate affinity/avidity (Table 1).

All of the 28 HEL-reactive clones were then assayed for their susceptibility to downregulation by $\mathrm{CD}^{+} \mathrm{T}$ cells, using flow cytometric analysis of $\mathrm{T}$ cell proliferation by serial halving of the fluorescence intensity of the vital dye CFSE as described in Methods. A representative inhibition assay is shown in Figure $2 \mathrm{~A}$ in which $\mathrm{CD}^{+} \mathrm{T}$ cells were added to HEL-reactive clones 13C9 and 9E4, described in Table 1. As shown, there was a dose-dependent inhibition of clone $13 \mathrm{C} 9$, with over $40 \%$ suppression observed at an effector-to-target ratio $(\mathrm{E} / \mathrm{T})$ of $10: 1$ and $18 \%$ suppression at an $\mathrm{E} / \mathrm{T}$ of $0.3: 1$. In contrast, there was no suppression when the same $\mathrm{CD}^{+} \mathrm{T}$ cells were added to the clone $9 \mathrm{E} 4$.

The $\mathrm{E} / \mathrm{T}$ needed for half maximum inhibition $\left(\mathrm{EI}_{50}\right)$ was used to measure the susceptibility of each $\mathrm{CD}^{+} \mathrm{T}$ cell clone to downregulation by the $\mathrm{CD}^{+} \mathrm{T}$ cells. As shown in Figure $2 \mathrm{~B}$ and Table 1, the high-affinity/avidity clones with $\mathrm{ED}_{50}$ below $1 \mu \mathrm{M}$ were resistant to downregulation. The susceptibility increased as a function of change of $\mathrm{ED}_{50}$, and the most susceptible range of $\mathrm{ED}_{50}$ was $4-12 \mu \mathrm{M}$. With the further increase of $\mathrm{ED}_{50}$, the clones gradually became less susceptible until they were almost completely resistant to the downregulation at $\mathrm{ED}_{50}$ above $20 \mu \mathrm{M}$. Thus, susceptibility to downregulation in vitro is, at least in part, a function of affinity/avidity of each $\mathrm{T}$ cell clone. Importantly, the $\mathrm{CD}^{+} \mathrm{T}$ cells preferentially downregulated target clones of intermediate affinity/avidity (in an $\mathrm{ED}_{50}$ range of roughly $1-20 \mu \mathrm{M}$ ) and tended to exclude clones of high and low affinity/avidity from downregulation. Five of the intermediateaffinity/avidity clones were further tested in antibody blocking experiments. As shown in Figure 2C, consistent with prior studies, the inhibition of these clones was blocked by mAbs to Qa-1, CD8, and TCR, but not control antibodies. The blockade by CD8 and Qa-1 mAbs is clearly consistent with the findings, described above, that these antibodies function in vivo to block the suppression by the $\mathrm{CD}^{+} \mathrm{T}$ cells. Taken together, these data support the hypothesis that $\mathrm{Qa}-1$-dependent $\mathrm{CD} 8^{+} \mathrm{T}$ cells play important roles in establishing and maintaining peripheral self tolerance to HEL in HEL Tg mice by selectively downregulating self-reactive T cells with intermediate affinity/avidity for HEL. 

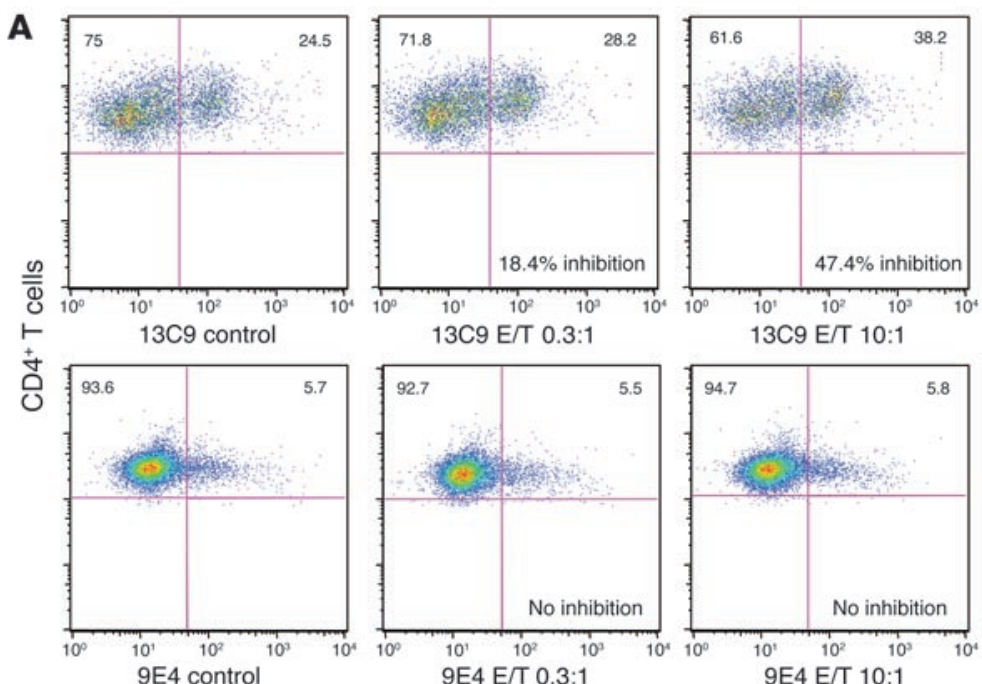

$13 \mathrm{Cg} \mathrm{E} / \mathrm{T}$ 0.3:1

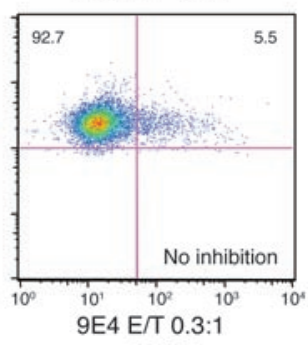

CFSE

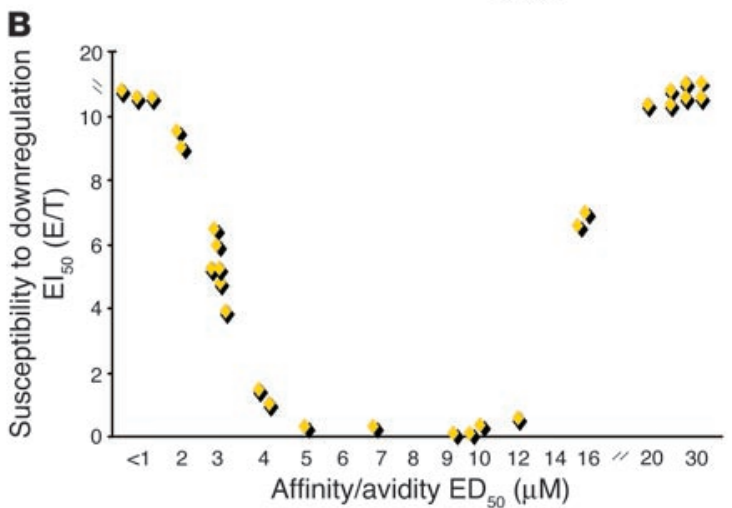

B

C

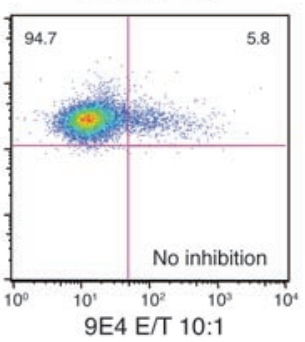$$
\text { 을 }
$$

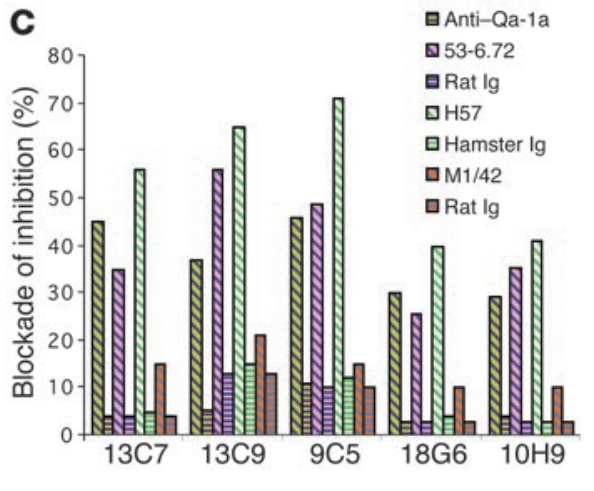

Figure 2

Qa-1-dependent CD8+ $\mathrm{T}$ cells selectively downregulate T cell clones of intermediate affinity/avidity for HEL. (A) In this representative example, the $\mathrm{CD}^{+} \mathrm{T}$ cells differentially downregulate a susceptible but not a nonsusceptible clone in a dose-dependent manner. The CD8 ${ }^{+} \mathrm{T}$ cells were directly mixed with CFSE-labeled testing clones as described in Methods. In this type of setting, we used non-CFSE-labeled activated clones to set up the cutoff line for undivided or less divided and more divided fractions for each clone individually. Since the autofluorescent background of each unlabeled activated clone in the FITC channel differs among clones, slightly different cutoff lines sometimes appear among different clones. Only 2 of $5 \mathrm{E} / \mathrm{Ts}$ for 2 representative clones, 13C9 (intermediate affinity/avidity) and 9E4 (high affinity/avidity), are shown. (B) Qa-1-dependent $\mathrm{CD}^{+} \mathrm{T}$ cells selectively downregulate HEL-specific $\mathrm{T}$ cell clones based on their affinity/avidity to HEL. In this set of tests, CD8 ${ }^{+} \mathrm{T}$ cells isolated from naive WT or HEL low Tg mice, which showed no effect on target $\mathrm{T}$ cells, were routinely used as control for the regulatory CD8 ${ }^{+} \mathrm{T}$ cells. (C) The downregulation of the intermediate-affinity/avidity clones by the CD8 ${ }^{+} \mathrm{T}$ cells is blocked by antibodies against TCR, Qa-1, and CD8, but not by the control antibody. The experiments were performed as described in Methods. Data represent experiments at $E / T s$ of $0.2: 1$ to $1: 1$, and final concentrations of $m A$ bs were $12.5-25 \mu \mathrm{g} / \mathrm{ml}$.

primary immune response $\left(1^{\circ}\right.$ HEL). A characteristic change associated with the increased proliferation was the decrease of ED $\mathrm{ED}_{50}$ between the $1^{\circ}$ and the $2^{\circ}$ immune response $\left(\mathrm{ED}_{50}\right.$ dropped from $40 \mu \mathrm{M}$ to $0.2 \mu \mathrm{M})$, indicating the increase of the overall affinity/avidity of HEL-reactive T cell population during the $2^{\circ}$ HEL response. Interestingly, the pattern of $\mathrm{T}$ cell proliferation of the $2^{\circ} \mathrm{HEL}$ response in the absence of Qa-1-dependent $\mathrm{CD}^{+} \mathrm{T}$ cells was markedly different. In the $\mathrm{CD}^{-} / 2^{\circ}$ HEL and Qa-1- $/ 2^{\circ}$ HEL mice, the maximum proliferation in response to HEL was shifted toward the higher antigen doses, revealing decreased overall affinity/avidity, even though the absolute proliferation was not significantly changed compared with that in $2^{\circ}$ HEL mice. Consistent with observations that regulatory $\mathrm{CD}^{+} \mathrm{T}$ cells do not affect the primary immune response in vivo in the EAE model and in Qa-1 KO mice $(4,11,21)$, we observed no effect of the treatment with mAbs to CD8 and Qa-1 on the in vivo primary HEL response in WT mice. These results thus strongly suggest that Qa-1-dependent $\mathrm{CD}^{+} \mathrm{T}$ cells are involved in affinity maturation during the secondary response to HEL in vivo in WT mice.

Qa-1-dependent $C D 8^{+} T$ cells selectively downregulate certain, but not all, HEL V $\beta 8.2$ clones expressing distinct canonical CDR3 sequence motifs. Because affinity maturation has been

$C D 8^{+} T$ cells participate in affinity maturation during the secondary immune response to $H E L$ in $W T B A L B / c$ mice. To further understand the suppressive effect of the $\mathrm{CD}^{+} \mathrm{T}$ cells on the immune response to foreign antigen, we tested the function of the $\mathrm{CD}^{+} \mathrm{T}$ cells in the HEL response in WT mice. We compared the overall affinity/avidity during the primary immune response with that during the secondary immune response to HEL in the presence and the absence of the Qa-1-dependent $\mathrm{CD}^{+} \mathrm{T}$ cells in vivo. $\mathrm{ED}_{50}$ was used to assess the overall affinity/avidity of HEL-responsive T cell populations $(19,20)$. As shown in Figure 3A, the proliferation of $\mathrm{CD} 4^{+} \mathrm{T}$ cells responding to HEL was dramatically increased during the secondary immune response $\left(2^{\circ} \mathrm{HEL}\right)$ compared with the shown by others to be associated with discrete changes in the TCR $V \beta$ repertoire, we next assayed the HEL-reactive TCR V $\beta 8.2$ repertoire following the primary and the secondary HEL immunization in the presence or absence of Qa-1-dependent CD8 T cells. We first assessed the TCR V $\beta 8.2$ repertoire by PCR-based CDR3 length distribution analysis, in the 4 experimental conditions $\left(1^{\circ} \mathrm{HEL}, 2^{\circ}\right.$ HEL, Qa- $1^{-} / 2^{\circ} \mathrm{HEL}$, and CD8 ${ }^{-} / 2^{\circ} \mathrm{HEL}$ ) described above (Figure $3 \mathrm{~A})$. As shown in Figure 3B, compared with $2^{\circ} \mathrm{HEL}$ mice, which possessed a single peak of CDR3 length of $10 \mathrm{AA}$, additional peaks appeared in both Qa- $1^{-} / 2^{\circ} \mathrm{HEL}$ and $\mathrm{CD} 8^{-} / 2^{\circ} \mathrm{HEL}$ mice. Because some clones persisted in the presence of $\mathrm{CD}^{+} \mathrm{T}$ cells in the secondary HEL V $\beta 8.2$ repertoire, this observation confirmed at a molecu- 

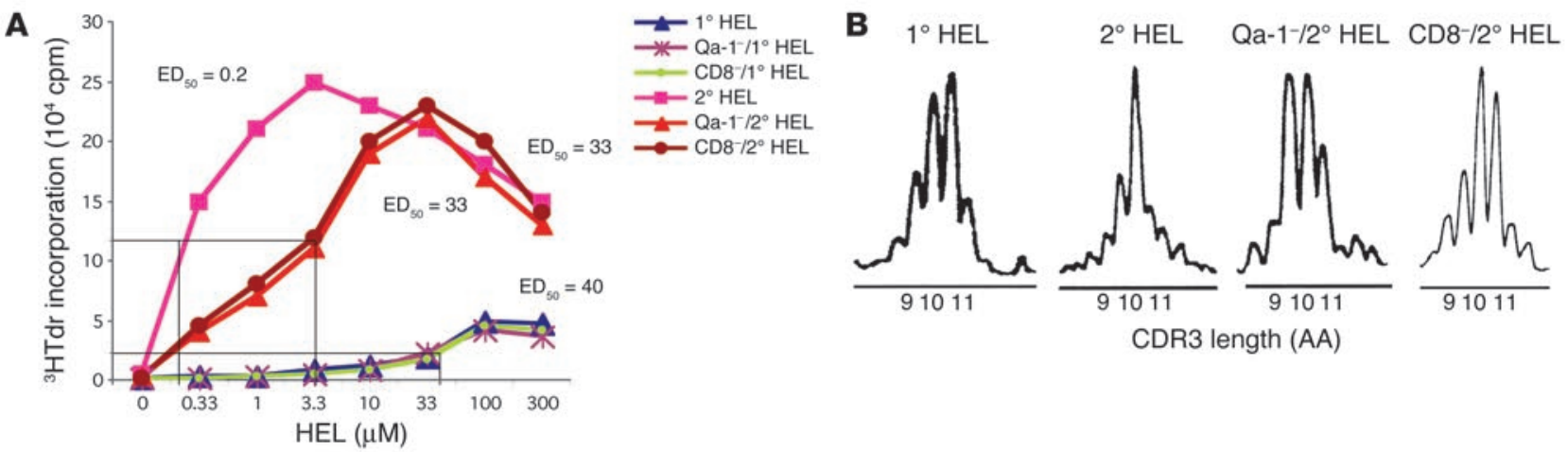

Figure 3

Qa-1-dependent CD8+ $\mathrm{T}$ cells facilitate maturation of affinity for HEL in WT mice. (A) Regulatory CD8+ $\mathrm{T}$ cells are involved in the increase of the overall affinity of HEL-reactive CD4+ $T$ cells during the secondary immune response to HEL in WT BALB/C mice. CD4 ${ }^{+} T$ cells were purified from pooled lymphocytes from draining lymph nodes of different groups of mice and assayed in a T cell proliferation assay as described in Methods. Data are representative of 3 separate experiments with 2-4 mice per group. (B) CD8 ${ }^{+} \mathrm{T}$ cells selectively downregulate certain HEL V $\beta 8.2$ clones in the secondary HEL-reactive repertoire in WT BALB/c mice. Mice were prepared as described in Methods. CD4+ $\mathrm{T}$ cells were isolated and purified from the draining lymph nodes on days 7-9 after the secondary HEL immunization and stimulated in vitro for a week. Analysis of distribution of the TCR CDR3 length of CD4+ $T$ cells isolated from the different groups of mice was performed as previously described (4, 47). Data are representative of 5 separate experiments with $2-4$ mice per group.

lar level that Qa-1-dependent CD8 ${ }^{+} \mathrm{T}$ cells selectively downregulate certain, but not all, HEL-reactive V $\beta 8.2$ clones in vivo.

We further defined the repertoire in the 4 groups of mice by sequencing the TCR V $\beta 8.2$ chains. A total of $231 \beta$ chain sequences were obtained and analyzed at the level of inferred AA sequence. As shown in Table 2 and Figure 4, in the range of CDR3 length from 9 to $11 \mathrm{AA}$, nearly $90 \%$ of the clones sequenced bore only 4 major canonical motifs (designated as types A, B, A/B, and C) and were characteristically distributed in the different HEL-reactive repertoires. As shown, type A clones, bearing the motif GTGN, represented only $8.3 \%$ of the primary HEL repertoire but $52 \%$ of the secondary HEL repertoire and were substantially reduced to $14.8 \%$ and $16.3 \%$, respectively, in the $\mathrm{Qa}-1^{-} / 2^{\circ} \mathrm{HEL}$ and $\mathrm{CD} 8^{-} / 2^{\circ} \mathrm{HEL}$ mice. Because the overall affinity/avidity of the secondary HEL repertoire increased (Figure $3 \mathrm{~A}$ ) and certain clones persisted in the secondary HEL repertoire in the presence of $\mathrm{CD}^{+} \mathrm{T}$ cells, the type A clones likely represent the high-affinity/avidity clones responding to HEL. In contrast, type B clones, bearing the motif GGX or GDP, did not appear at all in the primary and the secondary HEL repertoire. However, these clones only appeared in the Qa-1-/ $2^{\circ}$ HEL and CD8 $-/ 2^{\circ}$ HEL mice, where they represented about $30-40 \%$ of the HEL repertoire. Thus, type B clones, which emerge in the absence of Qa-1-dependent $\mathrm{CD}^{+} \mathrm{T}$ cells, are clearly under the control of the Qa-1-dependent $\mathrm{CD}^{+} \mathrm{T}$ cells. They are probably enriched in the intermediate-affinity/avidity $\mathrm{T}$ cell clones.

Type A/B clones express the GTGQ motif and have distribution characteristics of both type A and type B clones. Like type A clones, type $\mathrm{A} / \mathrm{B}$ clones were increased in frequency in the $2^{\circ} \mathrm{HEL}$ mice compared with the $1^{\circ}$ HEL mice. But like the frequency of type $B$ clones, the frequency of type A/B clones was lower in the $2^{\circ} \mathrm{HEL}$ mice compared with the Q $\mathrm{a}-1^{-} / 2^{\circ} \mathrm{HEL}$ and CD8 $-/ 2^{\circ} \mathrm{HEL}$ mice. Since there were still $45-60 \%$ of type A/B clones in $2^{\circ} \mathrm{HEL}$ mice in the presence of $\mathrm{CD}^{+} \mathrm{T}$ cells compared with type $\mathrm{A} / \mathrm{B}$ clones in Qa-1 $-/ 2^{\circ}$ HEL and CD8 $-/ 2^{\circ}$ HEL mice, these data are compatible with the idea that type A/B clones are only partially downregulated by the Qa-1-dependent $\mathrm{CD}^{+} \mathrm{T}$ cells. We thus envision that the type $\mathrm{A} / \mathrm{B}$ clones may represent clones in the range that overlaps high and intermediate affinity/avidity.

Type C clones bear either motif GD or GE. These clones occupied $72 \%$ of the primary repertoire. They were much reduced in the secondary repertoire regardless of the presence of $\mathrm{CD}^{+} \mathrm{T}$ cells. Thus type $\mathrm{C}$ clones are probably low-affinity/avidity clones that are not under the control of $\mathrm{CD}^{+} \mathrm{T}$ cells. The remaining clones bore diverse motifs and were equally distributed in the primary and the secondary repertoires regardless of the presence of $\mathrm{CD} 8^{+} \mathrm{T}$ cells. They are probably also low-affinity/avidity HEL clones that

Table 2

TCR V $\beta 8.2$ CDR3 sequence analysis of HEL-reactive repertoire in WT mice in the presence and absence of CD8+ T cells

\begin{tabular}{|c|c|c|c|c|c|c|c|c|c|c|c|}
\hline \multirow{3}{*}{$\begin{array}{l}\text { Unique motif sequences } \\
\text { Type of mice }\end{array}$} & \multicolumn{2}{|c|}{ Type A clones } & \multirow{2}{*}{\multicolumn{2}{|c|}{$\begin{array}{c}\text { Type A/B clones } \\
\text { GTGQ }\end{array}$}} & \multicolumn{4}{|c|}{ Type B clones } & \multirow{2}{*}{\multicolumn{2}{|c|}{$\begin{array}{c}\text { Type C clones } \\
\text { GD/GE }\end{array}$}} & \multirow{3}{*}{$\begin{array}{c}\text { Others } \\
\text { Diverse motifs } \\
\%\end{array}$} \\
\hline & \multicolumn{2}{|c|}{ GTGN } & & & \multicolumn{2}{|c|}{ GGX } & \multicolumn{2}{|c|}{ GDP } & & & \\
\hline & Freq & $\%$ & Freq & $\%$ & Freq & $\%$ & Freq & $\%$ & Freq & $\%$ & \\
\hline $1^{\circ} \mathrm{HEL}$ & $6 / 72$ & 8.3 & $4 / 72$ & 5.5 & $0 / 72$ & 0 & $0 / 72$ & 0 & $52 / 72$ & 72.2 & 14.0 \\
\hline $2^{\circ} \mathrm{HEL}$ & $26 / 50$ & 52.0 & $8 / 50$ & 16.0 & $0 / 50$ & 0 & $0 / 50$ & 0 & $8 / 50$ & 16.0 & 16.0 \\
\hline Qa-1-/2० HEL & $8 / 54$ & 14.8 & $20 / 54$ & 37.0 & $14 / 54$ & 25.9 & $2 / 54$ & 3.7 & $6 / 54$ & 11.1 & 7.5 \\
\hline $\mathrm{CD} 8^{-} / 2^{\circ} \mathrm{HEL}$ & $9 / 55$ & 16.3 & $15 / 55$ & 27.3 & $15 / 55$ & 27.3 & $3 / 55$ & 5.5 & $9 / 55$ & 16.3 & 7.3 \\
\hline
\end{tabular}

The TCR V $\beta$ CDR3 region was sequenced and analyzed as described in Methods. Freq, frequency. 


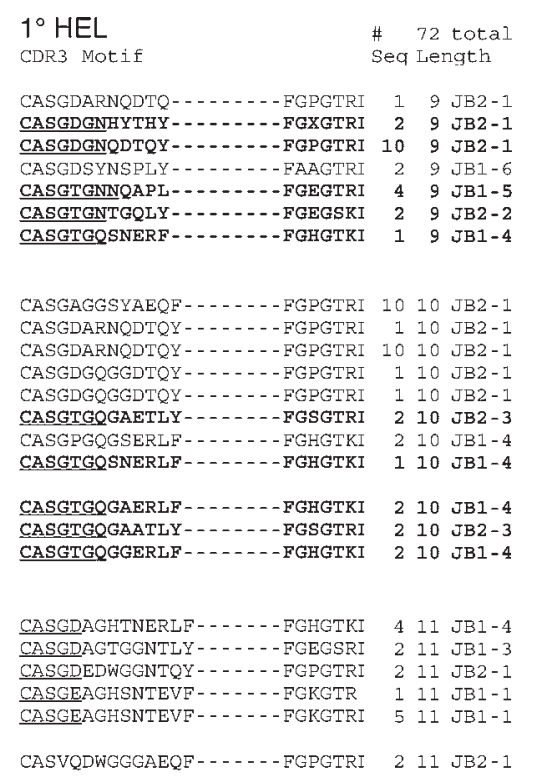

\begin{tabular}{|c|c|c|c|}
\hline $\begin{array}{l}\text { CD8 } 12^{\circ} \mathrm{HEL} \\
\text { CDR3 Motif }\end{array}$ & $\begin{array}{l}\text { \# } \\
\text { Sec }\end{array}$ & & $\begin{array}{l}\text { total } \\
\text { ngth }\end{array}$ \\
\hline CASGGGAQDTQY - - - - - - FGPGTRI & 1 & & $\mathrm{JB} 2-1$ \\
\hline CASGGKIQDTQY $\ldots \ldots$ FGPGTRI & 1 & & JB2-1 \\
\hline CASGTGNNQAPL & 4 & & $\mathrm{JB1}-5$ \\
\hline CASGIGNQDTQY $\ldots . . . . .-$ FGPGTRI & 2 & & $\mathrm{~GB} 2-1$ \\
\hline CASGTGNSYEQY - - - - FGPGTRI & 3 & & JB2-1 \\
\hline CASGDPGNTGQIY $-\cdots-$ FGEGSKI & 1 & 10 & $\mathrm{JB} 2-2$ \\
\hline CASGDQDRGDTLY $-\cdots-\cdots-$ FGXGTXI & 2 & 10 & JB1-5 \\
\hline CASGIGNSGNTLY - - - - FGEGSRI & 2 & 10 & $\mathrm{JBI}-3$ \\
\hline CASGIGQAAETLY $-1-1-$ FGSGTRI & 1 & 10 & $\mathrm{JB} 2-3$ \\
\hline CASGTGQGAETLY & 1 & 10 & $\mathrm{JB} 2-3$ \\
\hline CASGIGQNNERLF---1-FGHGKI & 12 & 10 & $\mathrm{JB1}-4$ \\
\hline CASGEANANSDYT $-\cdots-\cdots-$ FGSGTRI & 1 & 10 & $\mathrm{JB} 2-3$ \\
\hline CASGGDSSGNTLY & 2 & 10 & $\mathrm{JB} 1-3$ \\
\hline CASGGGTEGDTQY $-\cdots,-$ FGPGTRI & 1 & 10 & $\mathrm{JB} 2-1$ \\
\hline CATGIGQAAETIY-1-1-FGSGTRI & 2 & 10 & $\mathrm{JB2}-3$ \\
\hline CASGGPGQQDTQY $-\cdots---$ FGPGTRI & 2 & & JB2-1 \\
\hline CASGGTPSGNTLY $-\cdots-\cdots$ FGEGSRI & 2 & & $\mathrm{JB} 1-3$ \\
\hline CASGPGQYNSPLY $-\cdots-\ldots$ FAAGTRI & 1 & & JB1-6 \\
\hline GAGGGSAETLY - - - - - FGSGTRI & 2 & & JB1 - 2 \\
\hline CASGDEGGSNERLF - - - - - - FGHGTKI & 2 & & JB1-4 \\
\hline CASGDPTGGNERLF - - - - - - - - FGHGTKI & 2 & & JB1-4 \\
\hline CASGESRGPNERLF - - - - - - FGHGTKI & 1 & & JB1-4 \\
\hline CASGGGNSYNSPLY - - - - - FAAGTRI & 2 & & JB1- 6 \\
\hline CASGRDRESQNTLY - - - - - FGAGTRI & 2 & & JB2 -4 \\
\hline CASGTGNSYNSPLY - - - - FAAGTRI & 3 & & JB1-6 \\
\hline
\end{tabular}

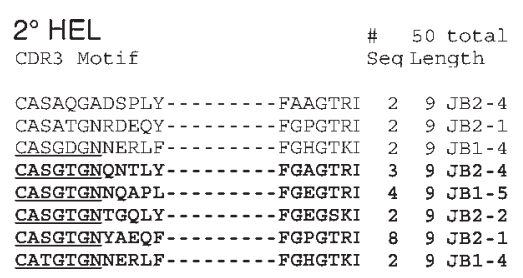

CASGDGDRNSDYT - . - . - - FGSGTRI $210 \mathrm{JB} 2-3$ CASGTGNSGNTLY-.....-.-FGEGSRI $410 \mathrm{JBI}-3$ CASGTGNSQNTLY-....-. - FGAGTRI 310 JB2-4 CASGTGOGATEVF-.....-.-FGKGTRI $210 \mathrm{JBI}-1$ CASGTGOIYAEQF-...-...-FGPGTRI $210 \mathrm{JB2}-1$

CASGTGOSNERLF-....--FGHGTKI $210 \mathrm{JB1}-4$ CASGTGOXXXEXF-...-.--FGXGTXI $210 \mathrm{JB} 2-3$ CASGTGONYAEQF -.....-. FGPGTRI $210 \mathrm{JB2}-1$

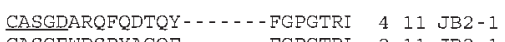
CASGDARQFQDTQY - . - - FGPGTRI 211 JB2-1

\begin{tabular}{|c|c|c|c|}
\hline $\begin{array}{l}\text { Qa-1-1/2 HEL } \\
\text { CDR3 Motif }\end{array}$ & $\begin{array}{l}\text { \# } \\
\text { Seq }\end{array}$ & & \\
\hline SATGNNQAPI- & 2 & 9 & JB2 - 1 \\
\hline ISGGDR IYEQY - & 2 & 9 & JB2-1 \\
\hline SGGGTQDTQY - - & 2 & 9 & JB2-1 \\
\hline TGGNTLY $\ldots \ldots-\ldots$ FC & 4 & 0 & JB2 -4 \\
\hline 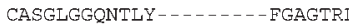 & 2 & 9 & JB2 -4 \\
\hline SGIGNNSPLY $-\cdots-\cdots-$ FI $^{\prime}$ & 6 & 9 & $J B I-6$ \\
\hline GTGNYAEQR - - - - - FGPGTR] & 2 & 9 & $J B 2-1$ \\
\hline LSGTGXXYXXY $\ldots \ldots-$ FGAGTXI & 2 & 9 & JB2 -4 \\
\hline$--F G$ & 4 & 10 & $\mathrm{JB} 2-1$ \\
\hline ATGGYEQY - - - - - - FGFGTRI & 2 & 10 & JE2-1 \\
\hline PWGTYEQY - - - - - FGPGTRJ & 2 & 10 & JB2 - 1 \\
\hline ASGGTSSAETLY - - - - -FGSGTRI & 2 & 10 & JB2 -3 \\
\hline 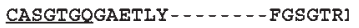 & 4 & 10 & \\
\hline _. & 4 & 10 & $J B 1-4$ \\
\hline SGTGQINERLF - - - - - - - FGHGTK] & 2 & 10 & JBI- 4 \\
\hline - - FGPGTRI & 4 & 10 & $J B 2-1$ \\
\hline - -PGKGTR] & 4 & 10 & JBI-I \\
\hline
\end{tabular}
$\begin{array}{lllll}\text { CASGAGTISNERLF- - - - - FGHGTK] } & 2 & 11 & \text { JB1-4 } \\ \text { CASGTGQVSNERLF-...--FGHGTK] } & 2 & 11 & \text { JB1-4 }\end{array}$

\section{Figure 4}

Actual CDR3 sequences of TCR V $\beta 8.2$ HELreactive repertoires in WT mice, representative 1 of the 5 experiments described in Figure $3 \mathrm{~B}$. CDR3 sequencing was performed as described in Methods.

understand the relationship between repertoires occupied by clones with unique canonical motifs and their affinity/avidity, we sequenced and compared the TCR $\mathrm{V} \beta 8.2^{+}$, HEL103-117-specific clones in the panel of 28 HEL-specific clones described in Table 1 . Only 4 clones were $\mathrm{V} \beta 8.2^{+}$and HEL103-117 specific among the 28 tested. This relatively low frequency probably reflects the fact that the panel of clones was generated and selected in order to increase the frequency of HEL-reactive clones at the lower end of the spectrum of affinity/avidity with different HEL peptide specificities. As shown in Table 2 and Table 3 , there is also a strong correlation between the unique canonical motifs from CDR3 sequences of the 4 identified HEL-specific clones with known affinity/avidity and susceptibility to downregulation by $\mathrm{CD}^{+} \mathrm{T}$ cells and the distinct distribution patterns of these motifs observed in different V $\beta 8.2$ HEL-reactive WT repertoires.

For example, 2 clones, 9E4 and 14F7, are high-affinity/avidity $\left(\mathrm{ED}_{50}\right.$ less than $1 \mu \mathrm{M}$ ) clones that are not susceptible to downregulation by $\mathrm{CD}^{+} \mathrm{T}$ cells in vitro $\left(\mathrm{EI}_{50}\right.$ greater than 10$)$ and are defined as type A by the CDR3 motif GTGN (Table 3 ). Consistent with the in vitro data, the in vivo data show that the $2^{\circ} \mathrm{HEL}$ repertoire with increased overall affinity/avidity for HEL in the presence of Qa-1-dependent $\mathrm{CD}^{+} \mathrm{T}$ cells was dominated by the type $\mathrm{A}$ clones (Table 2). Evidence that $\mathrm{CD}^{+} \mathrm{T}$ cells function to indirectly promote the growth of high-affinity/avidity $\mathrm{T}$ cell clones by

are not under the control of $\mathrm{CD}^{+} \mathrm{T}$ cells. We found a strong correlation between the change in overall affinity/avidity induced by in vivo $\mathrm{mAb}$ treatment of CD8 and Qa-1 and the change in frequencies of certain canonical CDR3 motifs in the HEL repertoires in these mice.

Comparison of unique motifs between HEL-specific TCR V $\beta 8.2$ clones and HEL-reactive TCR V $\beta 8.2$ repertoire. It is known that the HELreactive repertoire in WT mice is dominated by $\mathrm{T}$ cell clones that react to the dominant peptide HEL103-117 $(13,14)$. Furthermore, Cibotti et al. showed that the CDR3 sequences from the majority of hybridomas isolated from HEL-immunized WT mice ( 9 of 14 hybridomas) possessed the canonical motif GTGN or GTGQ (13). These observations are consistent with our data that $65 \%$ of the secondary HEL V $\beta 8.2$ repertoire in WT mice is occupied by the clones bearing the GTGN or the GTGQ motif (Table 2). To selectively downregulating intermediate-affinity/avidity clones is further provided by the analysis of the type A/B and type B clones. For example, in experiments, the third clone, 10H9, is at the high end of intermediate affinity/avidity, only moderately susceptible to downregulation by the $\mathrm{CD} 8^{+} \mathrm{T}$ cells $\left(\mathrm{EI}_{50}=5\right)$, and defined as a type A/B clone by the CDR3 motif GTGQ. Consistently in the analysis of the whole HEL repertoire, type A/B clones were generally partially downregulated by the $\mathrm{CD}^{+} \mathrm{T}$ cells (Table 2 ). The fourth clone, 20G10, is a type B clone defined by the CDR3 motif GDP. It is an intermediate-affinity/avidity clone with $\mathrm{ED}_{50}$ of $4 \mu \mathrm{M}$ and is susceptible to downregulation by the $\mathrm{CD}^{+} \mathrm{T}$ cells in vitro $\left(\mathrm{EI}_{50}=1\right)$. This observation is consistent with the data in Table 2 showing that type B motifs characterized intermediate-affinity/avidity clones that were suppressed in the presence of $\mathrm{CD}^{+} \mathrm{T}$ cells in vivo. Taken together, these data show that CD8 ${ }^{+}$ 


\section{Table 3}

Comparison between the canonical motifs from CDR3 sequences of identified HEL-specific clones with known $\mathrm{ED}_{50}$ and $\mathrm{El}_{50}$ and the analysis of the entire V $\beta 8.2$ HEL repertoire in WT mice

\begin{tabular}{|c|c|c|c|c|c|c|c|c|c|c|}
\hline \multirow[t]{2}{*}{ Clones } & \multirow{2}{*}{$\begin{array}{l}\mathrm{ED}_{50} \\
(\mu \mathrm{M})\end{array}$} & \multirow{2}{*}{$\begin{array}{c}\mathrm{El}_{50} \\
(\mathrm{E} / \mathrm{T})\end{array}$} & \multirow{2}{*}{$\begin{array}{l}\text { Type of } \\
\text { clones }\end{array}$} & \multirow[t]{2}{*}{$\mathbf{V} \beta$} & \multirow{2}{*}{$\begin{array}{l}\text { HEL peptide } \\
\text { specificity }\end{array}$} & \multirow{2}{*}{$\begin{array}{l}\text { V } \beta \text { CDR3 } \\
\text { sequence }\end{array}$} & \multicolumn{4}{|c|}{ Frequency of unique motifs in the HEL repertoire (\%) } \\
\hline & & & & & & & $1^{\circ} \mathrm{HEL}$ & $2^{\circ} \mathrm{HEL}$ & Qa-1-/2 ${ }^{\circ} \mathrm{HEL}$ & $\mathrm{CD} 8-/ 2^{\circ} \mathrm{HEL}$ \\
\hline 9E4 & $<1$ & $>10$ & A & 8.2 & $103-117$ & GTGNSGNTLY & 8.3 & 52 & 14.8 & 16.3 \\
\hline $14 \mathrm{~F} 7$ & $<1$ & $>10$ & A & 8.2 & $103-117$ & GTGNGNTLY & 8.3 & 52 & 14.8 & 16.3 \\
\hline $10 \mathrm{H} 9$ & 3 & 5.5 & $A / B$ & 8.2 & $103-117$ & GTGQGANTLY & 5.5 & 16.0 & 37.0 & 27.3 \\
\hline $20 \mathrm{G} 10$ & 4 & 1 & B & 8.2 & $103-117$ & GDPHRGRPEVF & 0 & 0 & 3.7 & 5.5 \\
\hline
\end{tabular}

The CDR3 region was sequenced and analyzed as described in Methods; unique motifs in the sequences are shown in bold.

T cells play a role in $\mathrm{T}$ cell affinity maturation to HEL in vivo by selectively downregulating $\mathrm{T}$ cells of intermediate affinity/avidity that respond to HEL.

\section{Discussion}

A unified mechanism for peripheral $T$ cell regulation of immune response to both self and foreign antigens. The major finding of the current study is that Qa-1-dependent $\mathrm{CD}^{+} \mathrm{T}$ cells are involved in both the development of peripheral tolerance to self antigen HEL in HEL Tg mice and the affinity maturation of $\mathrm{T}$ cells to foreignantigen HEL in WT mice. The strategy used by the Qa-1-dependent $\mathrm{CD}^{+} \mathrm{T}$ cells to accomplish these tasks in vivo is to selectively downregulate $T$ cell clones that are of intermediate affinity/avidity for HEL. We hypothesize that a unified mechanism used by the regulatory $\mathrm{CD}^{+} \mathrm{T}$ cells involves the recognition of a set of unique target antigens that are likely Qa-1/self peptide complexes differentially expressed on intermediate-affinity/avidity $\mathrm{CD} 4^{+} \mathrm{T}$ cells as a function of $\mathrm{T}$ cell activation. Subsequently, the Qa-1-dependent $\mathrm{CD}^{+} \mathrm{T}$ cells preferentially downregulate $\mathrm{T}$ cells of intermediate affinity/avidity to both self and foreign antigens.

In order to understand why the biological consequences of the selective downregulation of intermediate-affinity/avidity $\mathrm{T}$ cells are so different between responses to self antigen (preservation of tolerance) and to foreign antigens (facilitating affinity maturation), it is necessary to consider what is known about the peripheral TCR repertoires to self in contrast to foreign antigens. It is known that the affinity/avidity of TCRs to self antigen is the basis of central thymic negative selection and thus profoundly influences the formation of the naive peripheral TCR repertoires to both self and foreign antigens (22). During the negative selection, high-affinity/avidity selfreactive $T$ cells are deleted in the thymus (1). Clearly, a biological function of this central negative selection of high-affinity/avidity self-reactive clones is to eliminate the "immediate danger" of pathogenic autoimmunity in the periphery. However, to provide a sufficiently large mature $T$ cell pool to ensure the maximum flexibility of the peripheral repertoire to foreign antigens, in addition to the low-affinity/avidity self-reactive $T$ cells, thymic negative selection allows certain intermediate-affinity/avidity self-reactive $\mathrm{T}$ cells to be released into the periphery $(4,23)$. As a consequence, the periph-

\section{Figure 5}

An affinity/avidity model of peripheral T cell regulation. (A) The selective downregulation of intermediate-affinity/avidity T cells by the CD8 ${ }^{+} \mathrm{T}$ cells shapes the peripheral TCR repertoire to both self and foreign antigens during the evolution of immune response. (B) Cellular events involved in the Qa-1-dependent CD8+ T cell-mediated regulatory pathway. eral self-reactive repertoire is truncated and primarily composed of intermediate- and low-affinity/avidity self-reactive clones. On the other hand, the TCR repertoire to foreign antigens is composed of clones covering the entire spectrum of high, intermediate, and low affinity/avidity. Because the compositions of the naive peripheral TCR repertoires to self and foreign antigens are different due to thymic negative selection, the biological consequences of the selective downregulation of the intermediate-affinity/avidity $\mathrm{T}$ cells to self and foreign antigens are also different (Figure 5A). Preferential downregulation of the intermediate-affinity/avidity clones provides a mechanism to control the "potential danger" of pathogenic autoimmunity mediated by the $T$ cell clones enriched in the pool of intermediate-affinity/avidity self-reactive $\mathrm{T}$ cells in the periphery (4). The same mechanism is also used to preserve and select for clones with high affinity/avidity for foreign antigens, which are essential for effective immunity to infectious pathogens.

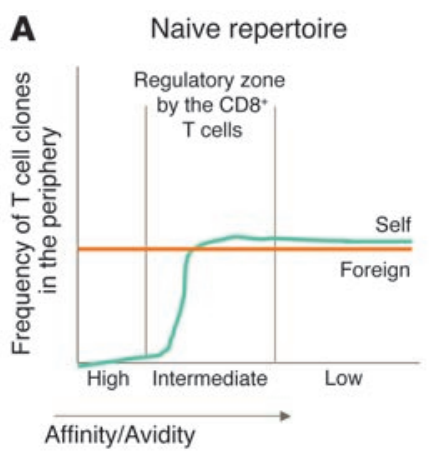

\section{Regulated repertoire}
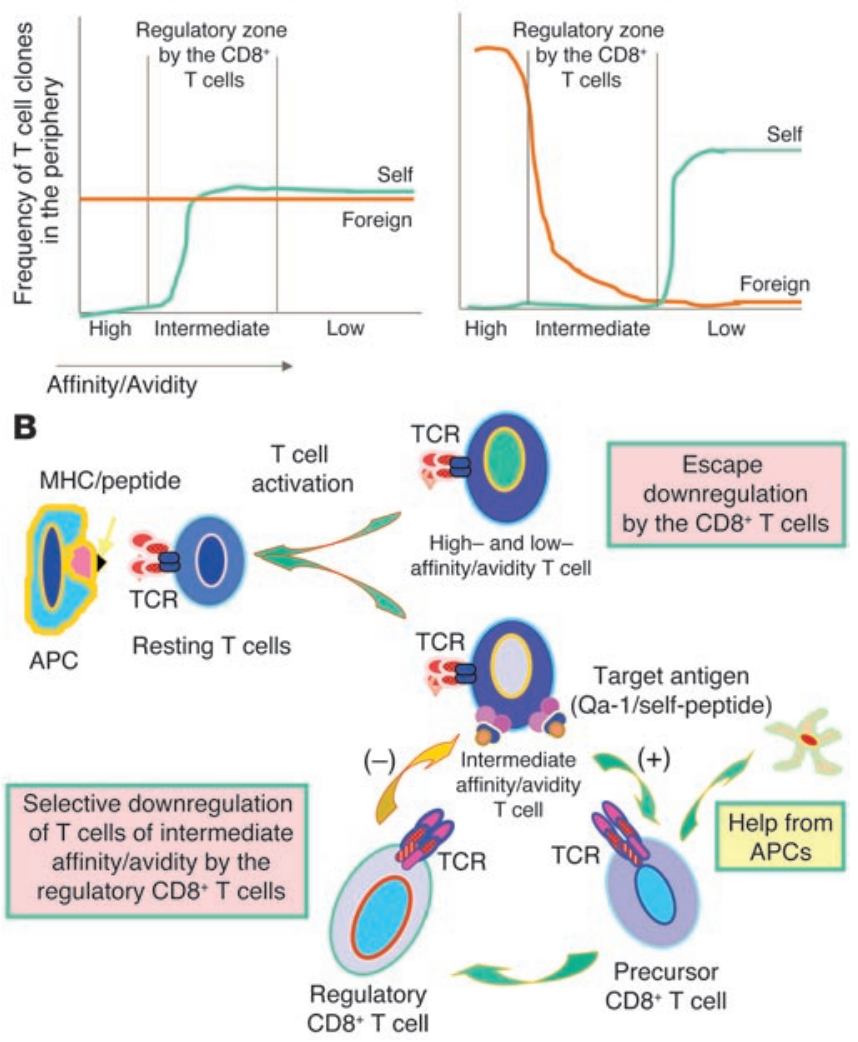
$\mathrm{CD}^{+} \mathrm{T}$ cells control peripheral self tolerance to HEL in HEL Tg mice. In the current studies we have provided what we believe to be the first experimental evidence that Qa-1-dependent $\mathrm{CD}^{+} \mathrm{T}$ cells participate in the establishment and maintenance of peripheral self tolerance in a classical HEL Tg animal model. It is of interest that the 2 types of HEL Tg mice represent 2 distinct immunological phenotypes of response to HEL, dictated by the different serum levels of this self antigen. The major difference between the high and low Tg mice is that self tolerance to HEL is internally induced in the high Tg mice and needs to be externally induced in the low Tg mice. Based on the "affinity model," we envision that, in high Tg mice, the intermediate-affinity/avidity $\mathrm{CD} 4^{+} \mathrm{T}$ cells escape intrathymic deletion and are activated by high levels of endogenous HEL (greater than $10 \mathrm{ng} / \mathrm{ml}$ ) in the periphery after birth. The activated intermediate-affinity/avidity $\mathrm{T}$ cells would trigger the regulatory $\mathrm{CD}^{+} \mathrm{T}$ cells. The primed regulatory $\mathrm{CD}^{+} \mathrm{T}$ cells in turn would selectively downregulate the activated intermediate-affinity/avidity HEL-reactive T cells in vivo. The remaining HEL-reactive T cells in the periphery would be of too low an affinity/avidity to elicit a response to HEL. In contrast, in HEL low Tg mice the serum level of endogenous HEL (less than $2 \mathrm{ng} / \mathrm{ml}$ ) is too low to effectively activate the intermediate-affinity/avidity T cells, which would otherwise in turn trigger the $\mathrm{CD}^{+}$ $\mathrm{T}$ cells. As a consequence, any intermediate-affinity/avidity HELreactive $\mathrm{CD}^{+} \mathrm{T}$ cells that have escaped thymic deletion are not downregulated in the periphery, because of lack of the primed regulatory $\mathrm{CD}^{+} \mathrm{T}$ cells in these mice after birth. However, following the first immunization with a high dose of HEL, HEL-reactive $\mathrm{T}$ cells of intermediate affinity/avidity are activated, and their presence is ascertained by standard in vitro proliferation assays (Figure 1B). As we have shown, the intermediate-affinity/avidity $\mathrm{T}$ cells activated during the primary immunization induce the regulatory $\mathrm{CD}^{+} \mathrm{T}$ cells. When mice are immunized with HEL the second time, the primed regulatory $\mathrm{CD}^{+} \mathrm{T}$ cells downregulate the intermediate-affinity/avidity $\mathrm{CD}^{+} \mathrm{T}$ cells that are activated by the secondary HEL immunization.

The preservation of low-affinity/avidity self-reactive $\mathrm{T}$ cells in the periphery by the $\mathrm{CD}^{+} \mathrm{T}$ cells is also of interest. It is known that low-affinity/avidity self-reactive $T$ cells may have high affinity/avidity for foreign antigens because of the structural plasticity of the TCRs (23-25). Thus, the low-affinity/avidity self-reactive T cells are preserved as part of the naive pool of the peripheral $\mathrm{T}$ cell repertoire to foreign antigens to contribute to its maximum flexibility (26).

$C D 8^{+} T$ cells are involved in the affinity maturation of immune responses to foreign antigens. To our knowledge, we have provided the first experimental evidence that $\mathrm{Q} a-1-$ dependent $\mathrm{CD} 8^{+} \mathrm{T}$ cells are also involved in the affinity maturation of the TCR repertoire during the secondary immune response to foreign-antigen HEL in WT mice. In this regard, during the evolution of immune responses to foreign antigens, both the antigen-specific B cell Ig and the TCR repertoire change and become more specific and composed of less diverse and higher-affinity/avidity clones responding to the same antigen (27-30). Furthermore, studies in several antigen systems have shown that there is also a change in antigen-specific response between the naive and the primary repertoires, which is evident during the first 5-6 days after primary priming with antigen peptides $(19,31)$. In these antigen systems, there is a first-level selection for "best fit" clones during the primary response, which shows that the primary antigen-specific repertoires are composed of a high frequency of clones with certain canonical motifs. Par- ticularly interesting are the studies by Fasso et al. in an SWM110121 system, which showed that the extremely high-affinity/avidity $\mathrm{T}$ cell clones (roughly, $\mathrm{ED}_{50}$ less than $0.02 \mu \mathrm{M}$ ) and the very low-affinity/avidity clones (roughly, $\mathrm{ED}_{50}$ greater than $50 \mu \mathrm{M}$ ) are competed out by the antigen-driven selection. The remaining primary repertoire is composed of intermediate-affinity/avidity clones with $\mathrm{ED}_{50}$ roughly between $0.05 \mu \mathrm{M}$ and $50 \mu \mathrm{M}$ (19). Our studies show that there is a second-level selection for the best fit clones between the primary and the secondary antigen-specific response. Thus, superimposed on the antigen-driven selection, the Qa-1-dependent CD8 ${ }^{+} \mathrm{T}$ cells participate in the fine-tuning of the secondary repertoire by selectively downregulating the intermediate-affinity/avidity $\mathrm{T}$ cell clones, which have $\mathrm{ED}_{50}$ values roughly between 1 and $20 \mu \mathrm{M}$, after the first-level selection achieved during the primary immune response.

The affinity/avidity model of peripheral $T$ cell regulation, mediated by Qa-1-dependent $C D 8^{+} T$ cells. The essence of the affinity/avidity model came from both in vivo and in vitro studies showing that the susceptibility of activated $\mathrm{CD} 4^{+} \mathrm{T}$ cells to downregulation by $\mathrm{CD}^{+} \mathrm{T}$ cells is determined by the affinity/avidity of the initial $\mathrm{T}$ cell activation. We envision that the regulatory pathway is composed of a series of sequential cellular events. As shown in Figure $5 \mathrm{~B}$, it is initiated by the activation of naive $\mathrm{CD} 4^{+} \mathrm{T}$ cells during the primary immune response, in which the TCR on $\mathrm{CD}^{+} \mathrm{T}$ cells interacts with MHC class II/antigen peptide complexes presented by conventional APCs. One of the consequences of the initial T cell activation is the differential expression of a specific target antigen on the surface of target $\mathrm{T}$ cells, which is likely to be Qa-1/ self peptide complexes. Importantly, the expression of the target antigen is determined by the affinity/avidity during the initial $\mathrm{T}$ cell activation. The target antigen is recognized by TCRs on regulatory $\mathrm{CD}^{+} \mathrm{T}$ cells. In this regard, since $\mathrm{T}$ cells are not "professional" APCs, the professional APCs, such as dendritic cells, may be recruited and function to provide costimulatory molecules during the induction phase of the regulatory $\mathrm{CD}^{+} \mathrm{T}$ cells. The target antigen expressed on certain activated $\mathrm{CD}^{+}{ }^{+} \mathrm{T}$ cells triggers the regulatory $\mathrm{CD}^{+} \mathrm{T}$ cells to differentiate into effector cells, which in turn downregulate the outgrowth of any $\mathrm{CD}^{+} \mathrm{T}$ cells expressing the same target antigen. A characteristic feature of the Qa-1-dependent $\mathrm{CD}^{+} \mathrm{T}$ cells is that they require priming by the activated $\mathrm{CD}^{+} \mathrm{T}$ cells during the primary immune response in order to regulate the secondary immune response in vivo. This distinguishes the $\mathrm{CD}^{+} \mathrm{T}$ cell regulatory pathway from other cellular regulatory pathways, including the NKT and the $\mathrm{CD} 4{ }^{+} \mathrm{CD} 25^{+}$ regulatory $\mathrm{T}$ cells, which exist as naturally occurring suppressor cells, function predominantly during the early and primary phases of the immune response, and do not require specific priming. This feature allows the immune system to more efficiently coordinate distinct regulatory pathways to control the peripheral immunity (21). Many aspects of this model need to be further clarified in future studies; a few are briefly discussed below.

First, we observed that the susceptibility of $\mathrm{CD} 4^{+} \mathrm{T}$ cells to downregulation by the $\mathrm{CD}^{+} \mathrm{T}$ cells is a function of affinity/avidity of the initial $\mathrm{T}$ cell activation, since the $\mathrm{CD}^{+} \mathrm{T}$ cells downregulate the HEL-specific clones based on their affinity/avidity for HEL. The affinity/avidity of each $\mathrm{T}$ cell clone in this study was determined by the $\mathrm{ED}_{50}$ using the antigen dose-response curve in a standard $\mathrm{T}$ cell proliferation assay $(19,20)$. It is known that $\mathrm{ED}_{50}$ reflects not only the affinity/avidity of the TCR on responding $\mathrm{T}$ cells but also the avidity of the initial interaction between the 
TCR and the MHC class II/antigen peptide complex. It may be influenced by the density of the TCR and the MHC/peptide complex (32) and by possible signaling via costimulatory molecules, including CD28, CTLA4, and CD40L, as well as by interactions with cytokines, chemokines, and integrins and their respective receptors (5). We certainly cannot rule out the possibility that the affinity/avidity of each $\mathrm{T}$ cell clone measured by the $\mathrm{ED}_{50}$ reflects the integrated effects of multiple signaling pathways during $T$ cell activation, which ultimately determines the expression of the target antigen and the susceptibility of the $T$ cells to downregulation by Qa-1-dependent $\mathrm{CD}^{+} \mathrm{T}$ cells.

Second, the exact threshold of the affinity/avidity of $\mathrm{T}$ cells that enables them to express the target Qa-1/self peptide structure, and to be subject to downregulation by the Qa-1-dependent $\mathrm{CD}^{+} \mathrm{T}$ cells, is unknown. There may not be an exact cutoff line for high- versus intermediate-affinity/avidity or intermediateversus low-affinity/avidity clones in relation to the susceptibility to downregulation. For example, in the boundary between high and intermediate affinity/avidity, there seems to be a transitional area of $\mathrm{ED}_{50}$ between 1 and $3 \mu \mathrm{M}$, which represents an apparent gradation of the susceptibility to downregulation by the $\mathrm{CD} 8^{+} \mathrm{T}$ cells (Figure 2B). Thus, we arbitrarily set the cutoff lines for intermediate affinity/avidity at $\mathrm{ED}_{50}$ of roughly 1-20 $\mu \mathrm{M}$. These cutoff lines represent rough estimates based on the transitional areas in the curve. These transitional areas may be flexible by their nature and may differ in different antigen systems and in different mouse strains bearing distinct $\mathrm{H}-2$ haplotypes.

Third, although the evidence that Qa-1 is associated with the function of the regulatory $\mathrm{CD}^{+} \mathrm{T}$ cells appears to be convincing, the precise role of $\mathrm{Qa}-1$ in the $\mathrm{CD}^{+} \mathrm{T}$ cell-mediated regulatory pathway has not been completely delineated. The known biological features of Qa-1, however, are of interest and may present teleological reasons why $\mathrm{Qa}-1$ was chosen to participate in $\mathrm{CD}^{+}$ $\mathrm{T}$ cell regulation. First, Qa-1 expression is dependent on $\mathrm{T}$ cell activation and is not expressed on resting $T$ cells. Therefore, naive $\mathrm{T}$ cells are spared downregulation. It is also known that the Qa-1 molecule displays little charge heterogeneity on resting lymphocytes but that the level of expression and degree of charge heterogeneity are both increased on activated lymphocytes (33). This indicates that the array of Qa-1-binding peptides changes during $\mathrm{T}$ cell activation. Second, Qa-1 is known to be an MHC class Ib molecule of limited polymorphism with the potential to present a relatively limited set of hydrophobic self peptides and foreign peptides to $\mathrm{CD}^{+} \mathrm{T}$ cells $(34,35)$. The predominant peptide bound to Qa-1 is Qdm, a hydrophobic peptide derived from the leader sequence of MHC class Ia molecules (36-39). Qdm binds with high affinity/avidity and accounts for the majority of the peptides associated with Qa-1 $(39,40)$. However, Qa-1 can also bind other hydrophobic self peptides and foreign peptides, including those derived from heat shock proteins (41) and preproinsulin leader sequences (42). We suggest that regulatory $\mathrm{CD}^{+} \mathrm{T}$ cells recognize a set of self peptides associated with Qa-1 and expressed selectively on certain activated $T$ cells. Thus, the most straightforward role for Qa-1 in the CD8 ${ }^{+} \mathrm{T}$ cell-mediated regulatory pathway could be that these Qa-1/self peptide complexes are differentially expressed on the surface of activated $\mathrm{CD} 4^{+} \mathrm{T}$ cells as a function of affinity/avidity and serve as the inducer and target antigen for the interaction with the $\mathrm{CD}^{+} \mathrm{T}$ cells.

Moreover, recent studies have shown that the majority of murine $\mathrm{CD}^{+} \mathrm{T}$ cells bind to Qa-1/Qdm tetramer and thus presumably express CD94/NKG2 receptors, the natural ligand for Qa-1/Qdm $(43,44)$, known to regulate the function of $\mathrm{CD}^{+} \mathrm{T}$ cells. This suggests that regulatory $\mathrm{CD}^{+} \mathrm{T}$ cells may coexpress 2 distinct types of Qa-1 receptors: $\alpha \beta$ TCR recognizing $Q a-1 /$ self peptide and the CD94/NKG2 receptor recognizing Qa-1/Qdm, which may either enhance or inhibit $\mathrm{CD}^{+} \mathrm{T}$ cell function. It is possible that in the intermediate-affinity/avidity clones, $\mathrm{T}$ cell activation results in the expression of Qa-1-binding peptides that compete with Qdm for binding to Qa-1 and interact with the TCRs on the CD8 ${ }^{+} \mathrm{T}$ cells. Thus, the differential expression of Qa-1/self peptide versus Qa-1/ Qdm, which cannot be distinguished by staining with the antibody to Qa-1, may play a crucial role in determining the susceptibility of the activated $\mathrm{T}$ cells to downregulation by the $\mathrm{CD}^{+} \mathrm{T}$ cells.

In summary, we have proposed and tested an affinity/avidity model of peripheral $\mathrm{T}$ cell regulation mediated by the CD8 ${ }^{+}$ $\mathrm{T}$ cells. We have demonstrated that Qa-1-dependent $\mathrm{CD}^{+} \mathrm{T}$ cells regulate the peripheral immune response by selectively downregulating $\mathrm{T}$ cells of intermediate affinity/avidity for both self and foreign antigens. We have also provided in vivo evidence that the biological function of this regulatory pathway is to establish and maintain peripheral self tolerance as well as to facilitate affinity maturation of the TCR repertoire to foreign antigens. These observations thus suggest that the immune system evolved to regulate peripheral immunity using a unified mechanism that efficiently and effectively permits the system to perform its essential functions to safeguard peripheral self tolerance yet to promote the capacity to deal with foreign invaders.

\section{Methods}

Animals. WT BALB/c mice were from The Jackson Laboratory. HEL Tg mice were generated at the Pasteur Institute (12). These Tg mice were bred in our animal facility, and the offspring bearing the HEL transgene were screened by PCR. A capture ELISA assay was established to measure the serum level of HEL. Three anti-HEL mAbs, D.11.15, F.9.13, and F.10.6.18, used in this work were generously provided by M. Riottot (Pasteur Institute) (16). Two types of HEL Tg mice were defined by the HEL serum level: high Tg mice, with serum levels greater than $10 \mathrm{ng} / \mathrm{ml}$, and low Tg mice, with serum levels less than $2 \mathrm{ng} / \mathrm{ml}$.

Ethical approval for animal experimentation was provided by the Institutional Animal Care and Use Committee at Columbia University.

Reagents. Anti-Qa-1b mAb was purified from supernatant of hybridoma 6A8.6F10.1A6 (45), and anti-Qa-1a antiserum was a kind gift from L. Flaherty (David Axelrod Institute for Public Health, Albany, New York, USA). The staining reagents were purchased from BD Biosciences - Pharmingen, including fluorescein-conjugated 53-6.72 (anti-mouse CD8), PE-conjugated GK1.5 (anti-mouse CD4), biotin-conjugated F23.1 (anti-mouse TCR

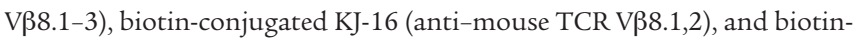
conjugated RR4.7 (anti-mouse TCR V $\beta 6$ ). Anti-MHC class Ia M1/42.39, anti-TCR V $\beta$ H57, anti-CD8, and anti-Qa-1b were purified from the supernatant of the hybridoma culture using a protein $\mathrm{G}$ column.

Immunization and in vivo mAb blocking protocols. In the standard protocol used throughout this study, mice were immunized with HEL once (the primary immune response, $1^{\circ} \mathrm{HEL}$ ) or immunized twice with HEL 1 week apart (the secondary immune response, $2^{\circ} \mathrm{HEL}$ ). HEL emulsified with CFA was injected into mice s.c. at $10 \mu \mathrm{M} /$ mouse. The groups of mice that were used for secondary immunization were treated with control Ig ( $\left.2^{\circ} \mathrm{HEL}\right)$, anti-Qa-1 mAb (Qa-1 $\left.{ }^{-} / 2^{\circ} \mathrm{HEL}\right)$, or anti-CD8 mAb $\left(\mathrm{CD} 8 / 2{ }^{\circ} \mathrm{HEL}\right)$ during the primary immunization (6). Anti-Qa-1 mAb was injected on days $-3,-1$, and 1 relative to primary HEL immunization at $0.2 \mathrm{mg} / \mathrm{mouse}$, and anti-CD $8 \mathrm{mAb}$ was injected at $0.3 \mathrm{mg} / \mathrm{mouse}$ 
on days -3 and -1 . The animals were then reimmunized with HEL, and, after 7-9 days, $\mathrm{CD} 4{ }^{+} \mathrm{T}$ cells purified from lymphocytes from draining lymph nodes were tested for their reactivity to HEL.

Purification of $C D 4^{+}$and $C D 8^{+} T$ cells. Both $\mathrm{CD}^{+}$and $\mathrm{CD} 4^{+} \mathrm{T}$ cells in all experiments presented in this paper were positively selected by MACS magnetic beads (Miltenyi Biotec Inc.) as previously described (10). Briefly, the lymph node cells were incubated with magnetic beads conjugated to anti-murine CD 4 or -murine CD8 at $10 \times 10^{6}$ cells per $10 \mu \mathrm{l}$ of beads, and the $\mathrm{CD}^{+}$and $\mathrm{CD}^{-}$populations were isolated using a separation column exposed to a magnetic field according to the manufacturer's protocol. The purity of the $\mathrm{CD}^{+}$or $\mathrm{CD}^{+} \mathrm{T}$ cells was greater than $95 \%$.

Adoptive transfer. The $\mathrm{CD}^{+} \mathrm{T}$ cells were isolated from immunized HEL Tg mice or WT mice as previously described (10). $\mathrm{CD}^{+} \mathrm{T}$ cells isolated from naive mice served as the control. CD8 ${ }^{+} \mathrm{T}$ cells $\left(2 \times 10^{6}\right.$ to $5 \times 10^{6}$ per mouse $)$ were adoptively transferred into naive recipient mice, which were immunized with HEL 1 day later. The responsiveness of the $\mathrm{CD} 4^{+} \mathrm{T}$ cells to HEL from the adoptively transferred mice was tested in the $\mathrm{T}$ cell proliferation assay as described below.

$H E L$ clones. BALB/c mice were immunized s.c. with HEL emulsified with $\mathrm{CFA}$, at $10 \mu \mathrm{M} /$ mouse. Seven days later, $\mathrm{CD}^{+} \mathrm{T}$ cells were purified from the draining lymph nodes and immediately cloned by limiting dilution as previously described (10). The clones were restimulated periodically with HEL or peptide(s) every 10-14 days at $10 \mu \mathrm{M}$. Since the cloning was performed immediately after isolation of the $\mathrm{CD} 4^{+} \mathrm{T}$ cells in vitro and relatively high doses of HEL were used to prime the T cells both in vivo and in vitro, we obtained clones with high, intermediate, and low affinity/avidity for different HEL peptides (10). A panel of CD4 $4^{+} \mathrm{T}$ cell clones was generated and characterized with respect to their HEL peptide specificity, TCR V $\beta$ expression, and affinity/avidity of each clone as measured by $\mathrm{ED}_{50}$ (described below). The $\mathrm{ED}_{50}$ value determined in the $\mathrm{T}$ cell proliferation assay as described below was used to determine the affinity/avidity of each clone.

Affinity/avidity of $T$ cells measured by $E D_{50}$. Single-cell suspensions were prepared from draining lymph nodes, and $5 \times 10^{5} \mathrm{lymph}$ node cells or $0.5 \times 10^{5}$ to $2 \times 10^{5}$ purified or cloned $\mathrm{CD}^{+} \mathrm{T}$ cells plus $5 \times 10^{5}$ irradiated splenic cells per well were plated in flat-bottom 96-well plates in AIM V serum-free lymphocyte medium (GIBCO; Invitrogen Corp.) supplemented with L-glutamine at $1 \mathrm{mM}$. HEL or HEL peptides were added in the concentration range of $0.03-300 \mu \mathrm{M}$. During the last 18 hours of 4-day culture, ${ }^{3} \mathrm{H}$-thymidine was added $(1 \mu \mathrm{Ci} /$ well $)$, and incorporation of labeling was measured by liquid scintillation counting. Cell proliferation, as cpm, was plotted against antigen concentration, and $\mathrm{ED}_{50}$ value was derived by calculation of the intercept of antigen concentration leading to half maximum proliferation $(19,20)$.

T cell inhibition assay. HEL-specific $\mathrm{CD} 4{ }^{+}$clones or lymph node cells from HEL-primed mice were labeled with CFSE and activated with HEL and APCs for 16-18 hours (46). T cells were then washed 3 times to eliminate free HEL and mixed with non-CFSE-labeled third-party cells, which are known not to be susceptible to downregulation by the $\mathrm{CD}^{+} \mathrm{T}$ cells. Graded numbers of $\mathrm{CD}^{+} \mathrm{T}$ cells isolated from the Tg or WT mice that received secondary HEL immunization were added into the mixture of control and testing targets. Wells without $\mathrm{CD}^{+} \mathrm{T}$ cells served as control. At 72 and 96 hours, cultured $\mathrm{T}$ cells were stained with PE-conjugated anti-CD8 mAb to gate out $\mathrm{CD}^{+} \mathrm{T}$ cells. Analysis of the ratios between remaining CFSElabeled testing-target clones and non-CFSE-labeled control targets was performed using a FACScan flow cytometer and CellQuest software (BD Biosciences) as previously described $(10,47)$.

Alternatively, the $\mathrm{CD}^{+} \mathrm{T}$ cells were directly mixed with CFSE-labeled testing clones. In this type of setting, we used non-CFSE-labeled activated clones to set up the cutoff line for undivided or less divided and more divided fractions for each $\mathrm{CD} 4^{+}$clone individually.
In both assays, we used the parameter "proliferation ratio," which is the ratio between CFSE-labeled testing clones and non-CFSE-labeled control targets (in the first assay) or the ratio between undivided or less divided and more divided fractions for each clone (in the second assay), to assess the inhibition by the $\mathrm{CD}^{+} \mathrm{T}$ cells. The proliferation ratios of the wells with the graded numbers of regulatory $\mathrm{CD}^{+} \mathrm{T}$ cells (experimental group) were compared with those of the wells without the $\mathrm{CD}^{+} \mathrm{T}$ cells (control) as a function of inhibition by the $\mathrm{CD}^{+} \mathrm{T}$ cells. The percentage of specific inhibition was determined as follows: $\%$ specific inhibition $=[$ (proliferation ratio of control - proliferation ratio of experimental group) / proliferation ratio of control] $\times 100$. CD8 ${ }^{+} \mathrm{T}$ cells isolated from naive WT or HEL low $\mathrm{Tg}$ mice served as controls for the regulatory $\mathrm{CD}^{+} \mathrm{T}$ cells in the inhibition assays and have never shown any effect on target $\mathrm{T}$ cells. Similar results were obtained from both settings of assays.

We chose the antigen dose of $10 \mu \mathrm{M}$ to stimulate all the clones tested, based on preliminary experiments in which we tested 3 representative antigen doses, 1,10 , and $30 \mu \mathrm{M}$, on more than half of the 28 HEL clones with different $\mathrm{ED}_{50}$. We found that all clones tested, in the range of $\mathrm{ED}_{50}$ between 0.1 and $33 \mu \mathrm{M}$, responded to 3 antigen doses, and, importantly, there were no significant differences in the susceptibility of each clone to downregulation by the $\mathrm{CD}^{+} \mathrm{T}$ cells at all 3 doses. Moreover, only clones with $\mathrm{ED}_{50}$ from 0.1 to $3 \mu \mathrm{M}$ proliferated well at a low antigen dose below $1 \mu \mathrm{M}$. This set of preliminary studies indicates that clones of $\mathrm{ED}_{50}$ greater than $20 \mu \mathrm{M}$ and less than $1 \mu \mathrm{M}$ are not susceptible to downregulation whereas clones of $\mathrm{ED}_{50}$ between $1 \mu \mathrm{M}$ and $20 \mu \mathrm{M}$ are susceptible, in a wide range of antigen doses. We thus chose $10 \mu \mathrm{M}$ as the dose for all 28 clones tested.

The susceptibility of the $\mathrm{T}$ cell clones to inhibition by the $\mathrm{CD} 8^{+} \mathrm{T}$ cells was measured by the index $\mathrm{EI}_{50}$, determined as the $\mathrm{E} / \mathrm{T}$ needed for half maximum inhibition by the $\mathrm{CD} 8^{+} \mathrm{T}$ cells for each clone in CFSE assay as described above.

Antibody blocking in the $\mathrm{T}$ cell inhibition assay was performed as previously described (10). Briefly, during the assay, anti-Qa-1 and anti-MHC class Ia, pan-mAb M1/42, or control mAbs were preincubated at room temperature with targets for half an hour, and anti-CD8 and anti-TCR mAbs were preincubated with $\mathrm{CD}^{+} \mathrm{T}$ cells at room temperature for half an hour before being mixed with targets. The controls for antibodies were anti-Qa-1a serum for anti-Qa-1b; rat Ig for M1/42 and the anti-CD8 mAb 53-6.72; and hamster Ig for the anti-TCR mAb H57.

$C D R 3$ length distribution (spectrotyping) and CDR3 sequencing analysis. Spectrotyping was performed as previously described $(4,48)$. The amplification of V $\beta 8.2$ cDNA was carried out using V $\beta 8.2$ primer 5 '-CATTATTCATATGGTGCTGGC-3' with CB2 primer 5'-GCCAGAAGGTAGCAGAGACC-3'. The extension of PCR products was carried out using CB5 primer 5'-CTTGGGTGGTAGTCACATTTCTC-3'.

The CDR3 sequence analysis was performed by extraction of total RNA from $\mathrm{CD}^{+} \mathrm{T}$ cell populations obtained from different groups of mice. The TCR VB8.2-specific PCR products of HEL-reactive CD $4^{+} \mathrm{T}$ cells were ligated into the PTOPO vector, and bacterial clones were obtained for TCR $\beta$ chain sequencing as described with some modifications $(4,48)$. Briefly, bacterial colonies were picked using toothpicks and placed in 25 $\mu \mathrm{l}$ of water in a 96 -well PCR plate. Bacteria $(1 \mu \mathrm{l})$ was added to a $20-\mu \mathrm{l} \mathrm{PCR}$ reaction mix containing $100 \mathrm{mM} \mathrm{KCl}, 20 \mathrm{mM}$ Tris- $\mathrm{HCl}$ ( $\mathrm{pH}$ 8.3), $2.5 \mathrm{mM}$ $\mathrm{MgCl}_{2}, 20 \mathrm{mM}$ TRBV and TRBC primer, $0.02 \mathrm{mM}$ dNTP, and $0.6 \mathrm{U}$ Platinum Taq DNA polymerase (Invitrogen Corp.). Initial incubation at $95^{\circ} \mathrm{C}$ for 120 seconds was followed by 30 cycles of $95^{\circ} \mathrm{C}$ for 30 seconds, $64^{\circ} \mathrm{C}$ for 30 seconds, and $72^{\circ} \mathrm{C}$ for 60 seconds, with a final extension of $72^{\circ} \mathrm{C}$ for 600 seconds. One microliter of this product was then used as template in a dye terminator sequencing reaction (48). The sequences obtained with CDR3 length between 9 and 11 AA, which represent over $95 \%$ of all bacterial clones sequenced, were analyzed as described previously $(4,48)$. 


\section{Acknowledgments}

The authors wish to thank Zhongping Sun, April Bingham, and Jianfeng Li for helpful discussions, support, and reagents, and Yihua Jiang for technical help. The research was supported by NIH grants AI39630 and AI44927 and National Multiple Sclerosis Society grant RG2938A (to H. Jiang), and NIH grant U19 AI/DK46132 (to L. Chess).

1. Kappler, J.W., Roehm, N., and Marrack, P. 1987. T cell tolerance by clonal elimination in the thymus. Cell. 49:273-280.

2. Bouneaud, C., Kourilsky, P., and Bousso, P. 2000. Impact of negative selection on the $T$ cell repertoire reactive to a self-peptide: a large fraction of $\mathrm{T}$ cell clones escapes clonal deletion. Immunity. 13:829-840.

3. Kuchroo, V.K., et al. 2002. T cell response in experimental autoimmune encephalomyelitis (EAE): role of self and cross-reactive antigens in shaping, tuning, and regulating the autopathogenic T cell repertoire. Annu. Rev. Immunol. 20:101-123.

4. Jiang, H., et al. 2003. Regulatory CD8+ T cells fine tune the MBP-reactive $\mathrm{T}$ cell receptor $\mathrm{Vb}$ repertoire during EAE. Proc. Natl. Acad. Sci. U. S. A 100:8378-8383.

5. Jiang, H., and Chess, L. 2000. The specific regulation of immune responses by CD8+ T cells restricted by the MHC class IB molecule, Qa-1. Annu. Rev. Immunol. 18:185-216.

6. Jiang, H., Zhang, S.I., and Pernis, B. 1992. Role of CD8+ T cells in murine experimental allergic encephalomyelitis. Science. 256:1213-1215.

7. Koh, D.-R., et al. 1992. Less mortality but more relapses in experimental allergic encephalomyelitis in CD8-/- mice. Science. 256:1210-1213.

8. Jiang, H., et al. 1995. Murine CD8+ T cells that specifically delete autologous CD4+ T cells expressing $\mathrm{V}$ beta 8 TCR: a role of the Qa-1 molecule. Immunity. 2:185-194.

9. Jiang, H., et al. 1998. T cell vaccination induces T cell receptor Vbeta-specific Qa-1- restricted regulatory CD8(+) T cells. Proc. Natl. Acad. Sci. U. S. A. 95:4533-4537.

10. Jiang, H., Braunstein, N.S., Yu, B., Winchester, R., and Chess, L. 2001. CD8+ T cells control the TH phenotype of MBP-reactive CD4+ T cells in EAE mice. Proc. Natl. Acad. Sci. U. S. A. 98:6301-6306.

11. Hu, D., et al. 2004. Analysis of regulatory CD8 T cells in Qa-1-deficient mice. Nat. Immuol. 5:516-523.

12. Cibotti, R., et al. 1992. Tolerance to a self-protein involves its immunodominant but does not involve its subdominant determinants. Proc. Natl. Acad. Sci. U. S. A. 89:416-420.

13. Cibotti, R., et al. 1994. Public and private V beta $T$ cell receptor repertoires against hen egg white lysozyme (HEL) in nontransgenic versus HEL transgenic mice. J. Exp. Med. 180:861-872.

14. Cabaniols, J.P., Cibotti, R., Kourilsky, P., Kosmatopoulos, K., and Kanellopoulos, J.M. 1994. Dosedependent $\mathrm{T}$ cell tolerance to an immunodominant self peptide. Eur. J. Immunol. 24:1743-1749.

15. Nanda, N.K., and Sercarz, E. 1996. A truncated $\mathrm{T}$ cell receptor repertoire reveals underlying immunogenicity of an antigenic determinant. J. Exp. Med. 184:1037-1043.

16. Gapin, L., et al. 1997. Determinant selection for T-cell tolerance in HEL-transgenic mice: dissociation between immunogenicity and tolerogenicity. Cell. Immunol. 177:77-85.

17. Maverakis, E., et al. 2000. T cell receptor comple-

Received for publication November 11, 2004, and accepted in revised form December 1, 2004.

Address correspondence to: Hong Jiang, Department of Medicine, College of Physicians and Surgeons, Columbia University, 630 West 168th Street, PH8-406, New York, New York 10032, USA. Phone: (212) 305-9988; Fax: (212) 305-4943; E-mail: hj4@columbia.edu.

mentarity determining region 3 length analysis reveals the absence of a characteristic public $\mathrm{T}$ cell repertoire in neonatal tolerance. The response in the "tolerant" mouse within the residual repertoire is quantitatively similar but qualitatively different. J. Exp. Med. 191:695-702.

18. Rees, W., et al. 1999. An inverse relationship between $T$ cell receptor affinity and antigen dose during CD4(+) T cell responses in vivo and in vitro. Proc. Natl. Acad. Sci. U. S. A. 96:9781-9786.

19. Fasso, M., et al. 2000. T cell receptor (TCR)-mediated repertoire selection and loss of TCR vbeta diversity during the initiation of a CD4(+) T cell response in vivo. J. Exp. Med. 192:1719-1730.

20. Targoni, O.S., and Lehmann, P.V. 1998. Endogenous myelin basic protein inactivates the high avidity T cell repertoire. J. Exp. Med. 187:2055-2063.

21. Jiang, H., and Chess, L. 2004. An intergrated model of immunoregulation mediated by regulatory $\mathrm{T}$ cell subsets. Adv. Immunol. 83:1-14.

22. Pullen, A.M., Marrack, P., and Kappler, J.W. 1988. The T-cell repertoire is heavily influenced by tolerance to polymorphic self-antigens. Nature. 335:796-801.

23. Sandberg, J.K., et al. 2000. T cell tolerance based on avidity thresholds rather than complete deletion allows maintenance of maximal repertoire diversity. J. Immunol. 165:25-33.

24. Garcia, K.C., et al. 1998. Structural basis of plasticity in T cell receptor recognition of a self peptideMHC antigen. Science. 279:1166-1172.

25. Kawai, K., and Ohashi, P.S. 1995. Immunological function of a defined T-cell population tolerized to low-affinity self antigens. Nature. 374:68-69.

26. Goldrath, A.W., and Bevan, M.J. 1999. Selecting and maintaining a diverse T-cell repertoire. Nature. 402:255-262.

27. McHeyzer-Williams, M.G., and Davis, M.M. 1995. Antigen-specific development of primary and memory T cells in vivo. Science. 268:106-111.

28. Savage, P.A., Boniface, J.J., and Davis, M.M. 1999. A kinetic basis for $\mathrm{T}$ cell receptor repertoire selection during an immune response. Immunity. 10:485-492.

29. Busch, D.H., and Pamer, E.G. 1999. T cell affinity maturation by selective expansion during infection. J. Exp. Med. 189:701-710.

30. Busch, D.H., Pilip, I., and Pamer, E.G. 1998. Evolution of a complex $\mathrm{T}$ cell receptor repertoire during primary and recall bacterial infection. J. Exp. Med. 188:61-70.

31. McHeyzer-Williams, L.J., Panus, J.F., Mikszta, J.A., and McHeyzer-Williams, M.G. 1999. Evolution of antigen-specific $\mathrm{T}$ cell receptors in vivo: preimmune and antigen-driven selection of preferred complementarity-determining region 3 (CDR3) motifs. J. Exp. Med. 189:1823-1838.

32. Kim, D.T., Rothbard, J.B., Bloom, D.D., and Fathman, C.G. 1996. Quantitative analysis of T cell activation: role of TCR/ligand density and TCR affinity. J. Immunol. 156:2737-2742.

33. Landolfi, N.F., Rich, R.R., and Cook, R.G. 1985.
The Qa-1 alloantigens. III. Biochemical analysis of the structure and extent of polymorphism of the Qa-1 allelic products. J. Immunol. 135:1264-1270.

34. Connolly, D.J., et al. 1993. A cDNA clone encoding the mouse Qa-1a histocompatibility antigen and proposed structure of the putative peptide binding site. J. Immunol. 151:6089-6098.

35. Shawar, S.M., Vyas, J.M., Rodgers, J.R., and Rich, R.R. 1994. Antigen presentation by major histocompatibility complex class I-B molecules. Annu. Rev. Immunol. 12:839-880.

36. Aldrich, C.J., Rodgers, J.R., and Rich, R.R. 1988. Regulation of Qa-1 expression and determinant modification by an H-2D-linked gene, Qdm. Immunogenetics. 28:334-344.

37. Aldrich, C.J., et al. 1992. T cell recognition of QA-1b antigens on cells lacking a functional Tap- 2 transporter. J. Immunol. 149:3773-3777.

38. Lowen, L.C., Aldrich, C.J., and Forman, J. 1993. Analysis of T cell receptors specific for recognition of class IB antigens. J. Immunol. 151:6155-6165.

39. Kurepa, Z., Hasemann, C.A., and Forman, J. 1998. Qa-1b binds conserved class I leader peptides derived from several mammalian species. J. Exp. Med. 188:973-978.

40. Cotterill, L.A., et al. 1997. Qa-1 interaction and T cell recognition of the Qa-1 determinant modifier peptide. Eur. J. Immunol. 27:2123-2132.

41. Imani, F., and Soloski, M.J. 1991. Heat shock proteins can regulate expression of the Tla regionencoded class Ib molecule Qa-1. Proc. Natl. Acad. Sci. U. S. A. 88:10475-10479.

42. Chun, T., et al. 1998. Constitutive and regulated expression of the class IB molecule Qa-1 in pancreatic beta cells. Immunology. 94:64-71.

43. Vance, R.E., Kraft, J.R., Altman, J.D., Jensen, P.E., and Raulet, D.H. 1998. Mouse CD94/NKG2A is a natural killer cell receptor for the nonclassical major histocompatibility complex (MHC) class I molecule Qa-1(b). J. Exp. Med. 188:1841-1848.

44. Salcedo, M., Bousso, P., Ljunggren, H.G., Kourilsky, P., and Abastado, J.P. 1998. The Qa-1b molecule binds to a large subpopulation of murine NK cells. Eur. J. Immunol. 28:4356-4361.

45. Lo, W.F., Ong, H., Metcalf, E.S., and Soloski, M.J. 1999. T cell responses to Gram-negative intracellular bacterial pathogens: a role for CD8+ T cells in immunity to Salmonella infection and the involvement of MHC class Ib molecules. J. Immunol. 162:5398-5406

46. Wells, A.D., Gudmundsdottir, H., and Turka, L.A. 1997. Following the fate of individual T cells throughout activation and clonal expansion. Signals from $\mathrm{T}$ cell receptor and CD28 differentially regulate the induction and duration of a proliferative response. J. Clin. Invest. 100:3173-3183.

47. Suchin, E.J., et al. 2001. Quantifying the frequency of alloreactive T cells in vivo: new answers to an old question. J. Immunol. 166:973-981.

48. Jabri, B., et al. 2002. TCR specificity dictates CD94/ NKG2A expression by human CTL. Immunity. 17:487-499. 